\title{
"PETE THE GREAT": A BIOGRAPHY OF PETER DOYLE
}

Martin G. Murray

Peter George Doyle's importance in the emotional life of Walt Whitman is well established. The romantic friendship that sprang up in 1865 between the streetcar conductor and the poet spanned the years of Whitman's residence in Washington, D.C., and continued nearly up through Whitman's death in Camden, in 1892. Yet despite the prominent role that Doyle played in Whitman's life, our knowledge of his personal history is incomplete. The following biography fills in some of the missing pieces about this enigmatic figure. ${ }^{1}$ In so doing, it hopes to give voice to the man John Burroughs hailed as "a mute inglorious Whitman."2

\section{A Boyhood in Ireland and Passage to America}

Until now, Doyle's actual birthday was a mystery to Whitman biographers. Peter Doyle himself claimed that he "was born in 1847, in Ireland."3 Whitman thought Doyle was born in Limerick on June 3, $1845^{4}$, while Pete's death certificate gave 1848 as his year of birth (NUPM, 2:891). To settle the question, I engaged Dr. S.C. O'Mahony of the Limerick Regional Archives to search for Doyle's baptismal record. ${ }^{5}$ O'Mahony found that Peter Doyle was baptised in the parish of St. John the Baptist Roman Catholic Church, Limerick City, Ireland on June 16, 1843. ${ }^{6}$ Presumably, Pete would have been baptised soon after his birth, as was the custom in those days. In that case, we can reasonably ascribe to Doyle a birth date of June 3, 1843.

Pete's parents were Peter Doyle and Catherine Nash. The couple were married in St. John's parish on January 16, 1831. Their children in birth order were:

John, baptised May 16, 1831;

Francis Michael, born on September 29, $1833 ;^{7}$

John, baptised June 29, 1836 (evidently the eldest boy died before this son was born); James, baptised July 17, 1839;

Elizabeth, baptised September 30, 1842;

Peter, baptised June 16, 1843;

Mary, baptised April 8, 1846;

Edward, baptised May 28, 1849; and

Margaret, born in Virginia in $1853 .^{8}$ 
Doyle claimed that he "was about two years old when brought to America" (Bucke, 21-22). A note Whitman made about Doyle, however, stated that Pete "came to America aged nearly 8 in March 1853 The heavy storm \& danger Good Friday night-1853-almost a wreck" (NUPM, 2:821). Whitman recollected that Doyle was "a bright-eyed little fellow - and the sailors took to him a good deal, as sailors do."9

Both Whitman and Doyle were slightly off the mark in their dating of Doyle's arrival. Peter Doyle was eight years old when he came to the United States from Ireland in 1852. He emigrated with his mother and brothers, John, James, and Edward. Their names can be found on the passenger list for the vessel William Patten. The ship, originating in Liverpool, England, arrived in Baltimore, Maryland on May 10, 1852. ${ }^{10}$ The full-rigged sailing ship that carried the family to America was captained by Charles Theobald. ${ }^{11}$ The ship was nearly wrecked at sea, as Whitman noted. The May 10,1852, edition of the Baltimore Sun stated that the vessel had "experienced a continued succession of easterly gales since April 1st; had bulwarks, stove, bowsprit carried away, \&c." The Good Friday storm to which Whitman referred would have occurred on April 9.

Presumably, Doyle's father and his brother, Francis Michael, came to this country at an earlier date. They were not listed as passengers on the William Patten. Perhaps Peter's sisters, Elizabeth and Mary, were victims of the Great Hunger that engulfed Ireland in the late 1840s. There is no record that the girls ever joined the other family members in America.

\section{Hometown Alexandria, Virginia}

Peter Doyle stated that his family spent its first years in America living in Alexandria, Virginia (Bucke, 22). This river port city on the Potomac is a few miles south of Washington, D.C. Catherine's brother, Michael Nash, lived in the District of Columbia, and probably influenced the Doyles' decision to settle in that area. The youngest Doyle child, Margaret, was born in Alexandria around 1853.

Peter Doyle, Sr., was a blacksmith (Bucke, 22). A likely place of employment was the Smith and Perkins Locomotive Works. ${ }^{12}$ Located on the Alexandria waterfront, the works included a machine shop, a foundry building, a blacksmith shop, a boiler shop, and a car shop. Smith and Perkins built coal-burning locomotives, at the rate of three per month, for railroads that included the Baltimore \& Ohio, Pennsylvania Central, Manassas Gap, and Hudson River companies. In 1852, the company employed some 200 men in its operations.

The social life of an Irish Catholic family like the Doyles would have been centered around St. Mary's parish. The original church 
building, still in use in 1994, was consecrated on March 4, 1827.13 Church tradition states that George Washington was an early benefactor of St. Mary's. He contributed to the building fund at its inception on July 14, 1793. The parish's first pastor, John Thayer, was a Boston native. Thayer had served Washington's Colonials as a Protestant minister before his conversion to Catholicism. Father Thayer's ministry led him eventually to St. John's in Limerick, Ireland. He lived there from 1803 until his death on February 5, 1815. ${ }^{14}$ It's likely that, as children, Peter, Sr., and Catherine Nash had heard Thayer speak of his Alexandria parish in Sunday sermons. During the 1850s, St. Mary's was a mission church staffed by the Jesuits of Georgetown College. Pete may have learned to read and write at the parish's Sunday School for Boys.

Doyle stated that the family left Alexandria in 1856-57 when "bad times came on" (Bucke, 22) during the general national depression. If his father worked for Smith and Perkins Locomotive Works, he would have lost his job when the firm declared bankruptcy in 1857 (Smith \& Miller, 77). Extant Alexandria municipal records list Peter Doyle as paying taxes in 1856 and 1858 . This suggests that the family moved in 1858 or 1859 . Doyle further remarked that the family went to Richmond, Virginia, where Doyle's father was offered employment in an iron foundry (Bucke, 22).

According to the 1860 Richmond city directory, Doyle worked as a blacksmith for Tredegar Iron Works. ${ }^{15}$ On the eve of the Civil War, Tredegar was the largest ironmaker in the South. ${ }^{16}$ The foundry employed eight hundred free workers and slaves, the fourth largest such employer in the United States (Dew, 20). Its free workforce consisted primarily of Irish and German immigrants (Dew, 28). During the Civil War, the Confederates relied heavily on the Tredegar works to supply it with arms. Among its many notable accomplishments during the war, it supplied the iron for the C.S.S. Virginia, better known as the Merrimac, for its historic battle with the Union ironclad, the Monitor (Dew, 118).

The 1860 Population Census for Richmond, enumerated on June 28 of that year, lists Peter Doyle, aged 47, a laborer, Catherine, aged 45, a dressmaker, and their children John, employed as a machinist, James, Peter, Edward, and Margaret.

\section{Pete the Rebel}

Doyle stated that he "was a member of the Fayette Artillery, and when the war broke out I entered the Confederate Army" (Bucke, 22). According to his Compiled Military Service Record, Doyle enlisted with the Richmond Fayette Artillery on April 25, 1861, a week and a day following the Virginia State Convention's adoption of an Ordinance of Secession on April 17. He served in the Confederate military for eigh- 
teen months and was discharged on November $7,1862 .{ }^{17}$ The official documents apparently inverted Doyle's first and middle names. $\mathrm{He}$ appears both as George P. Doyle and as Peter Doyle. He was seventeen years old when he enlisted. Military papers described Doyle as 5 feet 8 inches tall, with blue eyes, a light complexion, and light-colored hair. Doyle's civilian occupation was given as "cooper," that is, a barrel or cask maker.

Doyle's company was named in honor of the Marquis de Lafayette, upon the Revolutionary War hero's visit to Richmond in July $1824 .^{18}$ The company's association with Lafayette would have charmed Walt Whitman. The poet fondly remembered that, as a boy, he was "touched by the hands, and taken a moment to the breast of the immortal old Frenchman" during Lafayette's visit to Brooklyn Heights in $1825 .^{19}$

As a light artillery, the Richmond company provided field support for infantry units. The company's guns included four six-pounders (two of which had been used in the Revolutionary War and were given to the company by Lafayette in 1824), two ten-pounder Parrots, and one twelve-pounder howitzer (Moore, 14). Initially, the company consisted of one hundred and eight enlisted men and four officers (Moore, 4). Doyle was one of ten Irish natives in the battalion (Moore, 135).

The company spent a quiet first year at Gloucester Point, Virginia, opposite Yorktown (Moore, 4). During this assignment, Doyle was promoted, on October 27, 1861, from Private to Second Corporal. On February 8, 1862, apparently as part of a reorganization of the company under the Confederate States Act, most of the company's members, including Doyle, re-enlisted for a term of two years. Doyle received a re-enlistment bounty and a furlough to visit Richmond from February 20 through March 7.

\section{The Peninsula Campaign}

On February 22, 1862, the Fayette Artillery was ordered to Yorktown, Virginia (Moore, 9). In April, the company formed part of the Yorktown defenses as the city came under siege by General George McClellan's Union Army. McClellan's ultimate objective in the Peninsula Campaign was to capture the Confederate capital at Richmond by marching up the peninsula formed by the York and James rivers. During the Yorktown engagement, Doyle's company was under fire at Harrod's Mill on April 3 and at Wynn's Mill from April 5 until May 4 (Moore, 9).

Following the Confederates' withdrawal from Yorktown, the Fayette Artillery manned the defenses at Fort Magruder during the rearguard battle of Williamsburg. Three of Doyle's comrades-Delaware Branch, Delaware Crafton, and George Smith-were killed during the 
battle, and one-Joseph Beck-died three weeks later from wounds received (Moore, 144, 146, 150, 169). Nine other men in the company were also wounded (Moore, 11). Beginning with the May 1862 company roster, Doyle was listed as a Private, rather than as a $2 \mathrm{~d}$ Corporal.

On May 31, the Fayette Artillery participated in the far larger battle of Seven Pines, or Fair Oaks, at the gates of Richmond. ${ }^{20}$ Doyle and his comrades also took part in several battles of what would later be called The Seven Days Campaign, under a new commander, General Robert E. Lee, of what was now known as the Army of Northern Virginia. These battles were fought along the Chickahominy River, just outside the Confederate capital. The Richmond company fought at Gaines' Mill on June 27; Frayser's Farm or Glendale on June 30; and Malvern Hill on July 1 (Chamberlayne, 4). Although the latter battle was a Union victory, McClellan withdrew his army, much to President Lincoln's consternation.

The Peninsula Campaign took a heavy toll on the Fayette Artillery. Writing from Richmond on July 10, the company's 1st Lieutenant, William Izard Clopton, told his sister Joyce, "I was in all the fights on the Chickahominy \& terrible ones they were-my heart sickens when I think of the gallant spirits that then fled from us for ever. . . . Although I am unhurt, I am utterly broken down \& exhausted \& I am here for a few days to rest. I need it most sadly, for three months I have been thru' the most terrible service."21 In addition to those killed and wounded at Williamsburg, fourteen artillerymen were hospitalized from wounds or sickness suffered during the campaign, fifteen were AWOL at some point, and six men deserted (Moore, 143-174).

From July 11 through 23, Peter Doyle was away from camp on a detail to track down and arrest deserters. The Fayette Artillery was called to Manassas, Virginia. However, they did not arrive in time to take part in this battle, in which the Confederates repeated the victory won there the year before (Moore, 13).

\section{Blood and Water}

The Richmond company next took part in General Robert E. Lee's Maryland Campaign. In the battles of South Mountain and Antietam that followed, Doyle's Confederates squared off against Federal forces that included Walt Whitman's brother, George Washington Whitman.

The Fayette Artillery was assigned to General Lafayette McLaws's Division. The troops crossed the Potomac near Leesburg, Virginia, on September 6, 1862, and marched to Frederick, Maryland. The Confederates soon withdrew as the Federal forces advanced from Washington, D.C., and retook the city. Along with his comrades in the 51st New York Volunteers, George Whitman passed in review of General McClel- 
lan as the brigade marched through the western Maryland town. ${ }^{22}$

After leaving Frederick, the Richmond Fayette Artillery marched southwest. They took a position with Semmes' Brigade on South Mountain at the Brownsville Gap, just outside Burkittsville. They were engaged in battle there on September 14. Following the Confederate loss to the Union that same day in the nearby Crampton's Gap, the Fayette Artillery was summoned to Harpers Ferry, which fell to the rebels on September 15.

Meanwhile, George Whitman and the 51st New York Volunteers were also fighting on South Mountain. Whitman's company battled the enemy on the 7th of September, and again on the 14th, at Fox's Gap, approximately five miles north of Doyle's position at Brownsville Gap. ${ }^{23}$

Doyle and Whitman both saw heavy action in the battle of Antietam (referred to as the battle of Sharpsburg by the Confederates). As part of McLaws's Division, the Fayette Artillery marched all night from Harpers Ferry to Sharpsburg. They arrived in Lee's camp with the morning sun on September 17 (Moore, 15). After a brief rest, the Division reinforced General Stonewall Jackson's beleaguered troops, who were positioned in the west wood. McLaws's artillery, under the direction of Colonel Henry Cabell, the former captain of the Fayette Artillery, was in the heat of battle during the late morning and early afternoon. ${ }^{24} \mathrm{Lt}$. Clopton of the Richmond company described his feelings after this battle in a letter home:

At day-break on the 17th of September we recrossed into Maryland to re-inforce Genl. Lee \& were all day long in the great battle of Sharpsburg. This was a most terrific affair $\&$ at night both parties rested on their arms completely satisfied with each other with the dead \& wounded lying on the field. That is the most unnerving part of a fight to see the poor wounded fellows lying utterly helpless \& to hear their agonizing groans. We should have infalibly \& utterly routed the enemy but the men have straggled so much that one half our force could not be gotten into the fight. There is terrible management \& I suppose the commanding Genl. is responsible. ${ }^{25}$

In another part of the battlefield, George Whitman and the 51st New York Volunteers were occupied with taking Rohrbach Bridge, across Antietam Creek, better known ever since as Burnside's Bridge, after Union General Ambrose Burnside. Their much-celebrated crossing occurred early in the afternoon of the 17th (Sears, 266, 354). The Antietam National Battlefield Park today contains a monument to the men of the 51st New York, where the men took the bridge. ${ }^{26}$

Beginning that evening and continuing throughout the following day, Lee's Army of Northern Virginia withdrew to Winchester, Virginia. The Richmond company provided artillery cover for the withdrawal. These soldiers claimed to be the last to cross into Virginia (Moore, 16). 


\section{Doyle Is Discharged}

Evidently, Peter Doyle was wounded at Sharpsburg and sent to a hospital in Richmond, Virginia. From that city, Doyle petitioned the Confederate Secretary of War to discharge him from his military service. A Richmond notary public took Doyle's statement as follows:

State of Va.

City of Richmond to wit:

This day personnally appeared before me a Notary Public for the Said City in the State aforesaid, Peter Doyle, and made oath that he is not a Citizen of the Confederate States, that he was born in Ireland, in the Kingdom of Great Britain, and that he came to the Confederate States of America in the Spring of 1860, that he came from the City of Washington, D.C. where he had lived for three or four years that being the first place he stopped at after arriving in the United States. That he came to the City of Richmond, Va in the year 1860 in search of employment, and remained in the said city until 1861 when he joined the Fayette Artillery (Capt. Cabbell) for one year, and was mustered in the service of the Confederate States where he has remained ever since. That he has never acquired domicile in the said Confederacy, that he owns no property, never paid taxes nor voted in the said Confederacy, And that he has no family.

He asks the Hon. Secretary of War to discharge him from the army of the Confederate States.

[signed] Peter Doyle

Sworn and subscribed to before me this 14th day of Oct. 1862.

V. L. Atkinson, N.P.

The particulars of Doyle's testimony were supported by a John Smith who stated before Atkinson on October 14 that he had known Doyle in Washington, D.C. On October 31, 1862, Doyle made this additional statement to Atkinson:

And the affidant, Peter Doyle, further states on oath that he joined the Fayette Artillery, (Capt. Cabbell's company), on the 25th day of April, 1861, and that he does not intend to acquire a permanent residence in the Confederate States of America and that he intends to return to his native country, (Ireland), as soon as an opportunity will afford his doing so.

[signed] Peter Doyle

Sworn and Subscribed to before me this 31st day of Octr. 1862

V. L. Atkinson, N.P.

On the basis of this application, Doyle was granted a discharge by the Secretary of War on November 7, 1862.

Peter Doyle's statement in support of his discharge contained an equal measure of truths and half-truths. An Irish native, Doyle could claim allegiance to the British crown, but his residence in this country was twice as long as Doyle alleged, and it is unlikely that he actually 
intended to return to Ireland. I found no evidence of Doyle in Washington before the War, but it is possible that he lived there for a time with his brother, Francis Michael, or his uncle, Michael Nash, before joining his parents and siblings in Richmond. A teenager, Doyle presumably owned no property. Doyle had no wife nor offspring, but he did have a family consisting of his own parents and siblings living in the Confederate capital city.

In seeking a discharge, Doyle was probably motivated by a combination of war weariness and illness. From April through September of 1862, Doyle's company was engaged in arguably the most demanding series of battles fought during the war. Doyle's wartime service culminated in the battle of Antietam, which retains the dubious distinction of being the bloodiest single-day battle in American military history. It is possible that Doyle's battle wound was serious enough for him to feel unable to return to active service, although the hard-pressed Confederates may have been unwilling to discharge him solely on this basis. Even after Doyle received his discharge, his service record continues to show him as spending time in military hospitals. Whitman claimed that Doyle was an out-patient in Washington when the two men met (Johnston \& Wallace, 147).

Despite this renunciation, Doyle maintained, throughout his life, an identification with his Southern upbringing and pride in his Confederate military service. He was well-known to his friends as a former "Rebel." Later in life, he joined the United Confederate Veterans.

Doyle was one of five company members-Lucius Poitras, Charles Hutzler, Charles Matthias, and Andrew Baccigalupo were the other four-who were discharged in 1862 based on their claim that they had "never acquired a domicile" in the Confederate states (Moore, 144, 158, $162,166)$. In particular, Poitras, a Canadian, and Baccigalupo, a Sardinian, were discharged on the basis of their claimed alien status. ${ }^{27}$ Indeed, of the 106 men who enlisted as Privates with Doyle on April 25, 1861, in the Fayette Artillery, 40 men had been discharged or had deserted by the time Doyle received his discharge in November 1862 (Moore, 143-174).

While Doyle was gaining his discharge in Richmond, the Fayette Artillery was being reorganized. On November 23, 1862, the Richmond artillery became part of a battalion under the leadership of Captain James G. Dearing, Jr. (Moore, 65). A month after Pete left the military, his comrades in Dearing's (38th) Batallion took part in the battle of Fredericksburg, Virginia, on December 13, 1862. A minor facial wound George Washington Whitman received from an artillery shell at this battle caused his brother Walt to rush to the battle site from his Brooklyn home. Walt's desire to tend the wounded soldiers North and South kept him in Washington through the remainder of the war. 
Perhaps it was a shell lofted from Lee's Hill by one of Doyle's comrades in the Fayette Artillery that felled George Whitman, thus triggering the chain of events that resulted in Peter Doyle meeting Walt Whitman in Washington a few years later.

Although Doyle was discharged on November 7, 1862, his official military record contains several entries after this date. His name appears on the register of patients in General Hospital No. 2 in Richmond, Virginia; the record does not indicate when he was received into the hospital or for what illness he was treated, but it states that he was released on December 5, 1862. I have assumed that Doyle was wounded at Sharpsburg and admitted to the hospital shortly thereafter. This assumption is based on the fact that Doyle was in Richmond on October 14 and 31 (when he requested his discharge), while his company was at that time stationed in Winchester, Virginia. Also, Whitman stated that Doyle was wounded during the war (Johnston \& Wallace, 147).

More significantly, Doyle's name appears on a March 7, 1863, record of payment, in the amount of thirty dollars, to George Wright by Major John H. Parkhill, Quartermaster of the Confederate States Army. Wright received a bounty, "For arresting and delivering to Gen. John H. Winder at Richmond, Peter Doyle, a deserter from the Fayette Artillery." It remains unclear why Doyle, who had received a discharge in November 1862, was arrested for desertion four months afterwards. One possible explanation is that Doyle's company was never officially notified of the discharge and began proceedings against him. A second possibility is that the Richmond authorities had decided that the terms of Doyle's discharge were invalid. Doyle had claimed alien status and expressed an intention to return to Ireland but had remained in Virginia. In the Spring of 1863, there was a crackdown on foreigners who claimed exemption from military service but who continued to remain in Virginia. ${ }^{28}$ Such aliens were ordered to produce their papers at the office of General John H. Winder, the military provost of Richmond. As a result of Winder's action, there was a large exodus of foreigners from Virginia that Spring.

Doyle apparently was ordered to report back to his company, which was then stationed in Petersburg, Virginia (Moore, 67). The records of the Confederate States Hospital in Petersburg stated that a Peter Doyle of Dearing's Battalion (the battalion into which the Fayette Artillery was subsumed) was admitted on March 19, 1863. The records further stated that Doyle was released on April 17 to return to duty. At the time of his release from the hospital, Doyle's company was on duty in Suffolk, Virginia (Moore, 68-71). According to extant company muster rolls, Doyle never rejoined his outfit. ${ }^{29}$ 


\section{"Prison-escaping"}

What happened next to Doyle? In the Bucke interview, Doyle stated, "Being taken prisoner, happening in Washington, forced to look out for myself, I stayed in the Capital." 30 Whitman's note to himself remarked upon Doyle's "experience in the war-prison-escaping" (NUPM, 2:821). It's been assumed that Doyle was a prisoner of war. The story I have been able to reconstruct, based on material in the National Archives, suggests a different scenario. Apparently, after Doyle was released from the hospital in Petersburg, he decided against resuming life in the Confederate Army. Instead, he 'escaped' to the North. As he attempted to cross Federal lines, Doyle was captured by Union forces and taken to Washington, D.C. ${ }^{31}$ On April 18, 1863, he was confined in Carroll Prison, an annex to the Old Capitol Prison. ${ }^{32}$

Doyle was charged with "entering \& attempting to enter our lines, from the insurgent states, without a permit from the Federal authorities." In response to the charge, Doyle asserted that he was a British subject and a refugee from war-torn Virginia. Notice of Peter Doyle's imprisonment was made in Washington's Evening Star on Monday, April 20. The following day, Doyle's sister-in-law Ellen (nee Branzell) Doyle and Skip Branzell visited Pete at the Old Capitol. Ellen Doyle may have appealed to the British legation to secure Peter's release. On May 2, Secretary of State William Henry Seward requested information about Doyle's case on behalf of the British minister, Lord Lyons. Army Judge Advocate Levi C. Turner investigated the case. His report concluded that Doyle, and several other prisoners confined with him, were "poor Irishmen who fled from Richmond to avoid starvation. . . . They will not take oath of allegiance, but will give sworn parole." On May 11, Peter Doyle was released, after taking an oath not to aid the Rebellion.

\section{The Doyles in Washington}

Apparently, Peter Doyle's first job in D.C. was as a smith's helper at the Washington Navy Yard. A Peter Doyle is listed on the Yard's monthly payroll report from December 1863 until June $1865 .{ }^{33}$ During Confederate General Jubal Early's raid on Washington in July 1864, the 1,000 Navy Yard employees were organized into an ad-hoc militia to join in the defense of the Capital City. ${ }^{34}$ Whether Pete himself took arms against his former comrades in the Rebel army is unknown. At the Yard, Pete's daily wages increased from $\$ 1.50$ per day at the beginning of the period to $\$ 2.25$ per day at the end of the period. A James Doyle (Pete's brother?) was also employed as a smith's helper from February 1864 through February 1865 (nine days in the latter).

Initially, Pete lived with his brother, Francis Michael, and Francis's wife, Eleanor (or Ellen). Francis was nearly ten years older than 
Peter. Standing 5 feet 7 inches tall, Francis had gray eyes, brown hair, and a fair complexion, with a roguish scar on his left cheek. ${ }^{35}$ Unlike the rest of the Doyles, Francis never lived in Virginia. He had settled immediately in D.C. Francis married Eleanor Branzell, a Maryland native, on October 16, 1858. The marriage was performed in Washington, D.C., by Reverend L.F. Morgan, a minister of the Methodist Episcopal Church. ${ }^{36}$ Like his father, Francis was a blacksmith. He worked at the Washington Navy Yard in the late 1850s and early 1860 s. $^{37}$

At the outbreak of the Civil War, Francis had enlisted in Captain Robert Clarke's Company of the D.C. Military Infantry. ${ }^{38} \mathrm{He}$ joined the Union forces on April 24, 1861-just one day before his brother Peter enlisted as a Confederate soldier in Virginia. Francis served his full three-month term of enlistment. He was mustered out on July 24, 1861. Francis and Eleanor had a daughter Emma, born on July 31, 1864. Francis again joined the military in the War's closing months, enlisting on March 2, 1865, in the U.S. Navy. He served as a fireman aboard the Wasp until his discharge on April 18, 1867. After his military service ended, Francis joined the Metropolitan Police force on February 15, 1868. He and his wife, Eleanor, had two more children: Mary, born on June 12, 1868, and Robert Emmet (named after the Irish patriot), born on February 24, 1871. The children were brought up in their mother's church.

In addition to Peter and the Francis Doyles, the house at $62 \mathrm{M}$ Street, South (which would have been situated between 4th and 5th streets, SW in today's grid) also was home to brother James Doyle and Robert Branzell, who I assume was Eleanor's brother. ${ }^{39}$ James Doyle married in $1866 .^{40}$ His wife, Charlotte, gave birth that same year to a boy, James, and to a daughter, Kate, in 1869.

The Doyle brothers were eventually joined by their mother, Catherine, and younger siblings, Edward and Margaret, in the District. It remains unclear what happened to Peter's father. According to Whitman, Peter, Sr., went to New York in search of work, "and that was the last that was heard of him. No doubt he was drowned or killed" (Johnston \& Wallace, 147-148). ${ }^{41}$ The 1870 Population Census for the District of Columbia lists Pete, Jr., as the sole breadwinner and head of the household, which included his mother (listed as a widow), Edward, and Margaret. ${ }^{42}$

The Doyle households were within blocks of one another in the Southwest section of Washington. This area was popularly called "the Island" because it was "surrounded" by the Potomac, the Eastern Branch (now called the Anacostia), and the City Canal which connected these two rivers. The Island was home to a large community of European immigrants and newly freed slaves. 
Pete's uncle and aunt, Michael and Ann Nash, lived in a large, brick house they owned at 813 L Street, SE, a few blocks from the Navy Yard. They had two sons, Edward, a bricklayer, and William, a carpenter. Born in Limerick, Ireland, on May 1, 1805, Michael Nash came to this country about 1818. He lived the remainder of his life in the District of Columbia. ${ }^{43}$ As a young man, he was a member of the local militia and the volunteer fire department. Later, he was employed as superintendent of the shoemaking establishment connected with the old penitentiary. In time, he was a charter member and large stockholder of the Firemen's Insurance company and was also a stockholder in the Great Falls Ice Company.

Nash was married to Ann Maria Clarke. His wife was born on June 10, 1810, to Robert and Jane Clarke. ${ }^{44}$ Michael Nash owned two houses, in addition to the one he lived in, and several other pieces of property in the District. ${ }^{45}$ Nash was a member of the Association of the Oldest Inhabitants of the District of Columbia. This citizens group was founded in 1865 to "keep alive the reminiscences of the past and the social and paternal communion of the present." 46 Its membership included such prominent Washingtonians as banker and philanthropist William Wilson Corcoran and Benjamin Ogle Tayloe, an owner of the Willard Hotel. An annual tradition in which Nash took part was the New Year's Day call upon the President at the White House. ${ }^{47}$

The Nashes were communicants at St. Peter's Roman Catholic Church on Capitol Hill. Michael Nash may have been responsible for introducing Whitman to the parish's pastor, Reverend F.E. Boyle, to whom Whitman sent greetings in a letter to Doyle (Corr., 2:113).

\section{Clang, Clang, Clang . . .}

Evidently while still working at the Navy Yard, ${ }^{48}$ Peter Doyle began a second job as a horsecar conductor with the Washington and Georgetown Railroad Company. This company began operation on May 17, 1862, with a Congressional charter. The first route, along Pennsylvania Avenue from the Capitol to the Treasury, opened two months later. The three-mile journey cost a nickel and took 45 minutes. Service on the route was every five minutes. Eventually, the line was extended westward along Pennsylvania Avenue past Washington Circle and into Georgetown. It ended at Bridge and High streets (Wisconsin Avenue and $M$ streets, NW in today's grid). Eastward, the line went along Pennsylvania Avenue, headed south on Eighth Street, SE, passed the Marine Barracks, and ended up at the Navy Yard at M Street, SE. A line running north along Fourteenth Street, NW, from Pennsylvania Avenue to Boundary Street (now Florida Avenue), and one running the length of Seventh Street, NW, from the Potomac River to Boundary 
Street, were later added. ${ }^{49}$ The original 10 horsecar operation grew to one with 60 cars - running 941 trips daily - that carried over eight and a half million passengers in $1865 .^{50}$

The earliest cars consisted of a single-truck coach that measured fifteen by seven feet (Boettjer, 23). Passengers entered through the rear. The coach sat twenty persons on two silk velvet benches running along the sides of the car. The window panes were of stained and plain glass. The windows were covered with poplar blinds and damask curtains. The car's interior was lit by an oil lamp, covered by a red-tinted glass globe, which hung in the center of the car. The railroad also had open-air cars for summer use, with crosswise seats that accommodated twenty-four riders.

While a passenger one evening on Doyle's horsecar, the 45-year-old Whitman met the 21-year-old conductor. Doyle described their first encounter:

You ask where I first met him? It is a curious story. We felt to each other at once. I was a conductor. The night was very stormy,-he had been over to see Burroughs before he came down to take the car-the storm was awful. Walt had his blanket-it was thrown round his shoulders - he seemed like an old sea-captain. He was the only passenger, it was a lonely night, so I thought I would go in and talk with him. Something in me made me do it and something in him drew me that way. He used to say there was something in me had the same effect on him. Anyway, I went into the car. We were familiar at once-I put my hand on his knee-we understood. He did not get out at the end of the trip-in fact went all the way back with me. I think the year of this was 1866 . From that time on we were the biggest sort of friends. (Bucke, 23)

Although Doyle dated the meeting to 1866 , he and Whitman probably met in early 1865 . It seems likely that the encounter Doyle described occurred between January 23 and mid-March. The former date was when Whitman returned to D.C. from his six-month hiatus in Brooklyn (Corr., 1:248), and the latter date was when Whitman left Washington again to visit his family in New York (Corr., 1:255-256). (Whitman didn't return until after Lincoln's assassination in April.) This dating coincides with the fall-off in hours worked by Doyle at the Navy Yard in February 1865. This, in turn, suggests the approximate time that Doyle began his second job as a streetcar conductor. Doyle's reminiscence of their first meeting indicated a cold climate.

That Whitman and Doyle knew one another before the end of the Civil War is attested by two separate published remembrances. John Burroughs situated Doyle and Whitman on the streetcars together "toward the close of the war."51 (The last of the Confederate armies surrendered in June of 1865.) The writer Joel Sayre claimed that his father had met Whitman and Doyle on the horsecar toward the end of Whitman's tenure at the Bureau of Indian Affairs. ${ }^{52}$ (Whitman worked 
at the Bureau from January through June 1865.)

Additional evidence of their meeting in 1865 is provided by Whitman. In a Specimen Days entry dated "December 1865," Whitman suggested that he and Doyle were by then well-acquainted. Whitman also dated a photograph of himself and Doyle as taken in 1865 .

The attraction between Walt and Pete seems to confirm the cliché about opposites attracting. Physically, the six-foot tall, heavy-set, middle-aged Whitman towered over the young, five-foot-eight Doyle. Intellectually, Whitman was highly literate, both as a reader and a published author. In contrast, Doyle possessed only the rudimentaries of an education (albeit a "Jesuit education," at St. Mary's Sunday School for Boys). Whitman identified strongly with the Union as a native-born Easterner. Doyle, of course, was born in Ireland and raised in America's South; his first independent adult act was to fight against the Union.

In other respects, Whitman and Doyle were cut from the same cloth. Despite his white-collar occupations of journalist and government clerk, Whitman was at heart "one of the roughs." He felt most at home with the workingman that Doyle represented. For a time, Whitman had even taken up the carpenter's craft that his father had taught to Walt and the other Whitman boys. Whitman's brother, Andrew, worked in the Brooklyn Navy Yard, just as Doyle worked at its Washington counterpart. Whitman could identify with Doyle's emotional and financial responsibilities to a widowed mother and dependent siblings. Whitman was shouldering similar obligations himself. It is likely that Doyle's large, extended family served as a surrogate to Whitman's geographically distant own.

Peter Doyle was described by his niece, Mary Catherine, to her daughter Mary as "a homosexual." 53 This capacity in Doyle - to "love as I myself am capable of loving," as Whitman put it in his "Calamus" poem-cemented the bond between the two men. For the next eight years (until Whitman's stroke in 1873 caused his removal to Camden, New Jersey), Walt and Pete were constant companions.

Doyle bore some similarity to Fred Vaughan. This is the man whom Charley Shively has speculated was Whitman's lover during the late $1850 \mathrm{~s}$, when Whitman was writing his "Calamus" poems. ${ }^{54}$ Both Doyle and Vaughan were ethnic Irish; foreign-born (Vaughan was a native Canadian); railroad men (Vaughan was a Broadway stage coach driver and later a railroad engineer); and in their early twenties at the time of each man's involvement with Whitman. ${ }^{55}$ 


\section{Poet's Muse}

Doyle was an eyewitness to an American tragedy that had special significance to Whitman as a poet and a patriot. Doyle was present at the fateful performance of "My American Cousin" in Ford's Theater on Good Friday, April 14, 1865, when President Abraham Lincoln was assassinated. Doyle described the evening's events:

I heard that the President and his wife would be present and made up my mind to go. There was a great crowd in the building. I got into the second gallery. There was nothing extraordinary in the performance. I saw everything on the stage and was in a good position to see the President's box. I heard the pistol shot. I had no idea what it was, what it meant-it was sort of muffled. I really knew nothing of what had occurred until Mrs. Lincoln leaned out of the box and cried, "The President is shot!" I needn't tell you what I felt then, or saw. It is all put down in Walt's piece-that piece is exactly right. I saw Booth on the cushion of the box, saw him jump over, saw him catch his foot, which turned, saw him fall on the stage. He got up on his feet, cried out something which I could not hear for the hub-hub and disappeared. I suppose I lingered almost the last person. A soldier came into the gallery, saw me still there, called to me: "Get out of here! we're going to burn this damned building down!" I said: "If that is so I'll get out!" (Bucke, 25-26)

Doyle claimed that Whitman made use of Pete's eye-witness account for the poet's Lincoln lectures, given many years later. It is interesting to speculate in what other ways Doyle may have influenced Whitman's work. Was Pete the muse for Whitman's most popular Lincoln tribute, the poem, "O Captain! My Captain!"? Recall that the poem presents Lincoln as a ship's master, who dies just as the craft he piloted safely through a storm arrives at harbor. In developing this poem, Whitman may have sought to impress Doyle by making the Irish immigrant's own sea journey to America the central image of this heroic elegy to Lincoln ("The heavy storm and danger Good Friday night . . . almost a wreck," is how Whitman recalled Doyle's voyage). Both the president's assassination and Doyle's near wreck at sea occurred on a Good Friday. Whitman may also have broken from his own poetical tradition and adopted a near-metre rhyme to make the poem more appealing to the limerick-spouting Doyle. ${ }^{56}$ Interestingly, Whitman's first draft of "O Captain!" is written in free-verse, rather than rhymed metre. ${ }^{57}$ The captain of the poem may have been drawn from Doyle's description of Charles Theobald, the master of the immigrant ship that brought the Doyle family to this country. Or, it may have been drawn from Doyle's image of Whitman as an "old sea-captain" riding the horsecars. This of course presupposes that Doyle had described his voyage to Whitman by the time the poem was written; Whitman's notation about Doyle's voyage to America apparently was not made until 1875 (NUPM, 2:821). 
While "O Captain!" is remarkable for its use of rhyme, a second poem written at this time, "Come Up From The Fields Father," is unique in its use of a first name to identify the poem's fictional hero. The name used is "Pete." 58 Other than this one instance, Whitman never before or after in his poems used a personal name for a fictional character. ${ }^{59}$

The real life hero of "Come Up," however, was not Peter Doyle. Likely, it was Oscar Cunningham, the "Ohio boy" whom Whitman nursed at Armory Square Hospital. The young soldier died in 1864 . He was buried on the grounds of Arlington Plantation, the home of Colonel Robert E. Lee's wife, Mary Custis Lee (what is now Arlington National Cemetery). In particular, the poem takes place on an Ohio farm. The news of the son's illness is transmitted by a friend in the hospital writing to the boy's sister, just as Whitman wrote to Helen Cunningham. The letter-writer is ultimately mistaken about the son's condition, just as Whitman failed to communicate in time Oscar's imminent death to the Cunninghams. Whitman's decision to use the name "Pete" reflects an aesthetic decision. The first name of his new buddy strikes the required note of familiarity that the formal-sounding "Oscar" does not. It also suggests a transference to Doyle of the powerful emotions Whitman had felt toward the convalescing soldiers.

The "Calamus" emotions are expressed throughout the Drum-Taps poems. If Doyle did not directly inspire these poems, he at least reinforced the feelings underlying them, as Whitman was preparing the war poems for publication. This sentiment is seen especially in the following cases: the depiction in "Vigil Strange I Kept On The Field One Night" of the older soldier burying his "son of responding kisses, (never again on earth responding)" (LG Var., 2:491); the rover of "As Toilsome I Wander'd Virginia's Woods" coming upon the unknown soldier's grave with its rude inscription, "Bold, cautious, true, and my loving comrade" ( $L G$ Var., 2:509); the bitter-sweet remembrance of "The Dresser" "(Many a soldier's loving arms about this neck have cross'd and rested, Many a soldier's kiss dwells on these bearded lips)" (LG Var., 2:482); the loving gaze of "O Tan-Faced Prairie-Boy," which was valued in camp "more than all the gifts of the world" (LG Var., 2:507); "Reconciliation" with the dead enemy, "I draw near, I bend down and touch lightly with my lips the white face in the coffin" (LGVar., 2:556); and the poet's confession made "As I Lay With My Head In Your Lap Camerado" that "I confront peace, security, and all the settled laws, to unsettle them" (LG Var., 2:549). Whitman made a gift of the Drum-Taps manuscript to Pete (Bucke, 30). Perhaps this was Whitman's way of acknowledging the young man's creative influence on the poet during this fruitful period. 
The effects of his friendship with Doyle may also be seen in the 1867 edition of Whitman's Leaves of Grass. Whitman added several new poems but, more significantly, deleted three poems that had been in the "Calamus" section. As Florence Freedman noted in her biography of Whitman's knight-errant, William Douglas O'Connor, Whitman eliminated those poems that "expressed self-doubt and despair" but "kept those which expressed love and longing unaccompanied by despair." The excised poems were: "Long I Thought That Knowledge Alone Would Suffice," in which the poet renounces his vocation because "One who loves me is jealous of me, and withdraws me from all but love" ( $L G$ Var., 2:379); "Hours Continuing Long," in which Whitman writes, "Hours discouraged, distracted-for the one I cannot content myself without, soon I saw him content himself without me" (LG Var., 2:379); and "Who Is Now Reading This?" that has Whitman confessing to have "interior in myself, the stuff of wrongdoing," (LG Var., 2:386).

Freedman credits Whitman's more optimistic mood to "his finally having found 'lovers and avowers' of himself and of his poems in William and Nelly O'Connor, in Charles Eldridge, John Burroughs, and in the Washington circle of friends - with William as the central figure" (Freedman, 199-200). Freedman's focus was limited to the smart literary set and did not include the unlettered Doyle. It seems likely, however, that Walt's new-found confidence in love was, in large measure, a result of his satisfying friendship with Pete. The excisions can be interpreted as Whitman putting the unhappiness of his first "Calamus" love relationship with Fred Vaughan behind him as he embarked on this new love adventure.

\section{Loving Comrades}

Peter Doyle worked as a horsecar conductor from 1865 to 1872 . Whitman was a regular passenger on Pete's car, usually hopping aboard after his own workday was through at the Treasury Building. The two were a common and welcome sight in Washington. In his Birds and Poets, Burroughs recounted a journey on the streetcar with the two men. He portrayed Whitman "resting against the dash, by the side of the young conductor, and evidently his intimate friend" (Burroughs, 3:220). When Joel Sayre, Sr., and his brother, Warren, met Doyle and Whitman on the horsecars, the "gabby Irish conductor" was regaling the passengers with "a stream of jokes, delivered in brogue . . . There was furious bell-clanging; the horse car stopped, and who should get on but Walt. 'Walt, me bye!' the conductor shouted. There was great pumping of hands and clapping of shoulders. Then Walt caught sight of my father and yelled out his name. More pumping and clapping as brother Warren was introduced and the conductor, Peter Doyle" (Sayre). 
Dr. William Tindall read this account of a typical journey on the street railroad with Whitman and Doyle before the Columbia Historical Society on February 20, 1917:

It was one of my diversions to ride on the front platform with the driver in all kinds of weather except during thunderstorms. One of my occasional companions in that enjoyment on the cars of the Washington and Georgetown Railroad Company was the poet Walt Whitman, who preferred to ride on the front platform of a car on which a young man with light curly hair, whose name I think was Doyle, and whose appearance indicated Irish descent, was conductor. Whitman's custom was to get on the car of this conductor at the Treasury Department, where he was employed, after office hours, and ride toward the Navy Yard. During the rides with them in which I participated, their conversation, so far as I can remember, consisted of less than fifty words. It was the most taciturn mutual admiration society I ever attended; perhaps because the young Apollo was generally as uninformed as he was handsome, and Whitman's intellectual altitude was too far beyond his understanding to be reached by his apprehension or expressed by his vocabulary. The fellowship was a typical manifestation of the unconscious deference which mediocrity pays to genius, and of the restfulness which genius sometimes finds in the companionship of an opposite type of mentality.

The youthful grace of the conductor and the mature personality of the poet with iron-gray beard, slouch hat and rolling shirt collar that exposed a sturdy throat and enough of a broad chest to move with envy the modest young women of this day who affect the low-necked exposure, completed an ideal study in individual physical contrast. ${ }^{61}$

Doyle recalled that he and Walt would watch from the streetcar as President Grant strolled from the White House to visit Mrs. Magruder, widow of a well-respected local physician. Doyle also provided a rare glimpse of Whitman's anger in a streetcar incident. Whitman had rubbed up against "an old fellow (a fellow who was trying to represent the state of Virginia in the Senate)." The passenger cursed Walt, Walt issued an epithet in return, and the two came close to blows before Pete pulled them apart. ${ }^{62}$ Perhaps Walt's antagonist was Alexander Sharpe of Richmond, whom the Conservative/Democratic caucus in the Virginia Legislature unsuccessfully put up against the Unionist candidate, John Lewis, in the 1869 Senate campaign race.

Doyle recalled, "It was our practice to go to a hotel on Washington Avenue after I was done with my car. I remember the place well - there on the corner. Like as not I would go to sleep-lay my head on my hands on the table. Walt would sit there, wait, watch, keep me undisturbed-would wake me up when the hour of closing came" (Bucke, 24-25). Doyle's recollection is strikingly reminiscent of Whitman's "Calamus" poem, "A Glimpse": 
One flitting glimpse, caught through an interstice,

Of a crowd of workmen and drivers in a bar-room, around the stove, late of a winter night - And I unremark'd seated in a corner;

Of a youth who loves me, and whom I love, silently approaching, and seating himself near, that he may hold me by the hand;

A long while, amid the noises of coming and going - of drinking and oath and smutty jest,

There we two, content, happy in being together, speaking little, perhaps not a word.

(LG Var., 2:397)

The bar that the two patronized was in Georgetown's Union Hotel, at the corner of Washington and Bridge streets (30th and M streets, NW in today's grid).$^{63}$ During the first two years of the Civil War, the hotel had been used as a hospital for patients with contagious diseases. In the winter of 1862-63, Louisa May Alcott nursed the wounded soldiers there. Her Hospital Sketches were drawn from that experience. ${ }^{64}$

Unlike the physical wreck of his last years, Whitman was, by Doyle's recollection, "an athlete-great, great. I knew him to do wonderful lifting, running, walking" (Bucke, 23). Walt and Pete were especially fond of taking long hikes together out of the city. A favorite destination of the wanderers was Doyle's American hometown of Alexandria, Virginia. The two would cross over the Potomac River's Eastern Branch via the Navy Yard Bridge, wander south along the Maryland side of the river, and take the ferry across to Virginia. Then the rovers headed back home, following the Potomac on the Virginia side. Crossing the Long Bridge into the District's Island neighborhood, Whitman saw Pete to his home.

Doyle recalled that Walt was "always whistling or singing. We would talk of ordinary matters. He would recite poetry, especially Shakespeare-he would hum airs or shout in the woods" (Bucke, 26). Whitman told Horace Traubel, "We would walk together for miles and miles, never sated. Often we would go on for some time without a word, then talk-Pete a rod ahead or I a rod ahead. . . . It was a great, a precious, a memorable experience. To get the ensemble of Leaves of Grass you have got to include such things as these-the walks, Pete's friendship: yes, such things: they are absolutely necessary to the completion of the story." 65

Their jaunts would occasionally be interrupted. A shout from behind of "After all not to create only!" would signal the arrival of Ohio Congressman James Garfield (Bucke, 32). The former Brigadier General in the Union Army was a good friend of Walt's, despite his persistent ribbing about the poor reception accorded Whitman's 1871 address to the American Institute.

Sometimes, Whitman would simply not be in the mood to be accosted. Doyle recalled one particular incident in which the intruder quickly was made to understand this: 


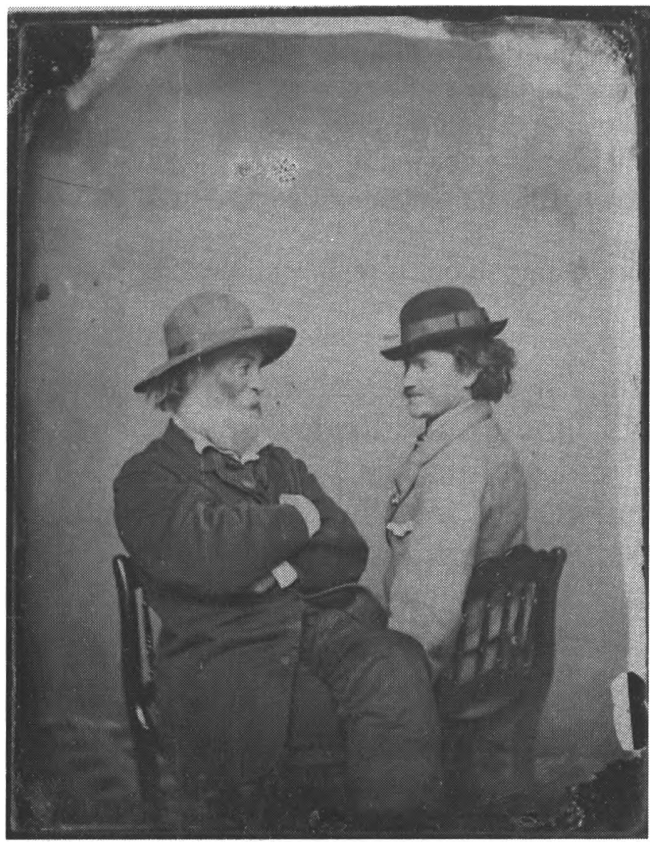

Figure 2. Whitman and Doyle, around 1868. Photograph by M. P. Rice, Washington, D.C. Charles E. Feinberg Collection.

I remember one special night. We met a half-loaded fellow with some of his friends, George Alfred Townsend, 'Gath' he is now called, \& some other newspaper boys. George was officiously familiar with Walt-insisted on introducing his friends, \& all that \& Walt held him off-froze him out - would not be introduced. It was impossible for Townsend to make his point. Now, Walt was always dignified - simple enough, too $-\&$ this was a sample of the manner he showed to all alike-famous or plain folks-who stepped across what he thought his private border-line. ${ }^{66}$

Whitman's love for the photographer's lens is well known. On at least two occasions, he brought Pete along with him for a sitting. In the better-known picture, the two are seated facing each other, each with a silly grin (see Figure 2). Whitman once asked Thomas Harned (his future literary executor) what the poet's look suggested. Harned offered, "Fondness, and Doyle should be a girl" (Traubel, 3:543). In a more serious pose, Whitman is seated looking over at Doyle, who faces the camera squarely as he stands by the older man's side (see Figure 1). More flattering to Pete's good looks than either of the photographs with Whitman is a solo portrait taken on July 5, 1868 (see Figure 3). ${ }^{67}$ The photographer captured Doyle's handsome, moon-shaped face, with the wispy mustache drooping over full lips, a sharp gaze in his right eye, and a lazy, withdrawn look in the left, and a head of thick, curly hair, 
barely contained by a rakish leather cap. All three photographs were taken in the studio of Moses P. Rice, located on Pennsylvania Avenue between 2nd and 3rd streets, NW.

\section{"Dear Pete": the Correspondence}

Although Whitman and Doyle's friendship dates to early 1865, the first extant correspondence between them is in the fall of 1868. At the time, Whitman was in New York visiting family and friends. The very first surviving letter of what was to prove a long correspondence was from Pete, written on September 18. ${ }^{68} \mathrm{He}$ exclaimed, "I could not resist the inclination to write to you this morning it seems more than a week since i saw you" (Shively, 104). On September 25, Walt declared, "I think of you very often, dearest comrade, \& with more calmness than when I was there-I find it first rate to think of you, Pete, \& to know that you are there, all right, \& that I shall return, \& we will be together again. I don't know what I should do if I hadn't you to think of \& look forward to" (Corr., 2:47). In the six weeks that they were apart, Doyle wrote at least seven times, and Walt wrote eleven times (Corr., 2:67).

Doyle's letters to Walt were full of the small events of daily life that Whitman so loved to hear. "Pete the Great" (as he signed himself) described his trip to the baseball game where he saw the Olympics clobber Cincinnati. He visited the theater to see the Black Crook- "i had no idea that it was so good. Some of the scenes was magnificent" (Shively, 106). He shared with Walt the gossip about the Railroad men-"Jim Sorrill sends his love \& says Charley's baby is well and doing first rate . . . I would like to send you a Picture of Dave as i write this, he is about two thirds asleep in one end of the car while i sit in the other end writing this letter" (Shively, 108). Pete sent on the Washington papers, including an article in the September 18 Daily Morning Chronicle about Whitman's visit to Brooklyn. He also sent him the September 30 Evening Star, which contained an account of Chicago written by Whitman's friend and the Star's editor, Crosby Stuart Noyes: "Mr. Noyes ... . was on my car . . \& \& he looks first rate i told him i sent you the star containing his letter and it seemed to please him very much" (Shively, 107-108).

On his side, Whitman recounted the sights, sounds and smells of the East River, a Democratic Party torchlight parade, and his publishing endeavors (Corr., 2:55-56). Whitman told Doyle of his side trip to Providence, Rhode Island. There he was the guest in the home of Dr. William Francis Channing and his wife, Jeannie (Ellen O'Connor's sister). He also stayed with former Congressman Thomas Davis. Satisfied with his comfortable arrangements, Walt crowed, "So you see, Pete, your old man is in clover" (Corr., 2:60). Whitman remarked at the 
abundance of fresh fruits and flowers at his host's home: "Pete, I could now send you a bouquet every morning, far better than I used to, of much choicer flowers" (Corr., 2:61).

Walt and Pete jested about Whitman's flirtations with young women. First, Pete ribbed Walt about a comment made by Jim Sorrill concerning the "young Lady that said you make such a good bed fellow" (Shively, 106-107). Whitman responded directly to Sorrill within a letter to Pete: "Dear Jimmy: You may not understand it, what that lady said about the bedfellow business, but it's all right \& regularbesides, I guess you understand it well enough" (Corr., 2:51). Later, writing on October 18 from Thomas's home in Providence, Whitman joked about his coquettish exchanges with the women there:

You would be astonished, my son, to see the brass \& coolness, \& the capacity of flirtation \& carrying on with the girls - I would never have believed it of myself . . . Of course, young man, you understand, it is all on the square. My going in amounts to just talking \& joking \& having a devil of a jolly time, carrying on-that's all . . . So long, dear Pete $-\&$ my love to you as always, always. (Corr., 2:62-63)

Pete's last letter to Whitman that Fall, sent October 14, mentioned attending the wake for a cousin who had died. Perhaps this was Robert E. Taylor, who the Evening Star for Saturday, October 10, mentions had died that day, "aged 31 years, 5 months, and 6 days." According to the paper, Taylor was waked at the residence of Pete's uncle, Michael Nash, on October 12. After sending love from "all the boys," Doyle signed the letter, "Pete X X" (Shively, 109).

The two men corresponded during Whitman's summer 1869 vacation to Brooklyn. In Whitman's first letter to Doyle, written on August 21, he castigated Pete for the young man's overreaction to a skin disorder troubling him. Apparently, Doyle was so distraught that he spoke of committing suicide. Edwin Haviland Miller noted that Whitman uncharacteristically warned Pete of "hell's agonies hereafter" should he do such a thing, exploiting Doyle's Catholic upbringing to convince Doyle not to kill himself. Walt promised the young man:

My darling, if you are not well when I come back I will get a good room or two in some quiet place, (or out of Washington, perhaps in Baltimore,) and we will live together, \& devote ourselves altogether to the job of curing you, \& rooting the cursed thing out entirely, \& making you stronger \& healthier than ever. I have had this in my mind before, but never broached it to you. I could go on with my work in the Attorney General's office just the same-\& we would see that your mother should have a small sum every week to keep the pot a-boiling at home . . . Dear comrade, I think of you very often. My love for you is indestructible. (Corr., 2:84-85)

Doyle's hysterical response to what Dr. Richard Maurice Bucke later diagnosed as barber's itch may have been influenced by a series of advertisements appearing in the local papers. Placed by the Baltimore 
Lock Hospital ("A Refuge From Quackery," so it claimed), and promising "Skin Diseases Speedily Cured," the ads preyed upon the sexual guilt of young adults:

DR. JOHNSTON HAS DISCOVERED THE most Certain, Speedy, and only Effectual Remedy in the World for Weakness in the Back or Limbs, Strictures, Affection of the Kidneys and Bladder, Involuntary Discharges, Impotency, General Debility, Nervousness, Dyspepsia, Languor, Low Spirits, Confusion of Ideas, Palpitation of the Heart, Timidity, Trembling, Dimness of Sight or Giddiness, Disease of the Head, Throat, Nose, or Skin, Affections of the Liver, Lungs, Stomach, or Bowels-those terrible Disorders arising from Solitary Habits of Youth-SECRET and solitary practices more fatal to their victims than the song of Syrens to the Mariners of Ulysses, blighting their most brilliant hopes or anticipations, rendering marriage, \&c. impossible.

YOUNG MEN

especially, who have become the victims of Solitary Vice, that dreadful and destructive habit which annually sweeps to an untimely grave thousands of young men of the most exalted talents and brilliant intellect, who might otherwise have entranced listening Senators with the thunders of eloquence, or waked to ecstacy the living lyre, may call with full confidence. ${ }^{69}$

The Lock Hospital did sufficiently good business hawking a cure for this 'malady' that it could afford to run this full-column advertisement several days a week, for months at a time.

From Walt's letters to Pete that summer, it appears that Doyle soon shook his moroseness about his own health. Whitman himself wasn't well that summer, but he minimized his illness to keep Pete from worrying about him. Whitman mentioned that his "particular women friends" had sent for him, although he had not been to see them (Corr., $2: 87)$. Walt did find the time to ride the East River ferries: "Some of the pilots are dear personal friends of mine-some, when we meet, we kiss each other (I am an exception to all their customs with others)" (Corr., $2: 88$ ).

References in the 1868 and 1869 correspondence by both Doyle and Whitman to the latter's capacity for flirting with women are curious, given the assumption that Whitman and Doyle were "lovers" in the contemporary sense of the word. It seems especially odd that Whitman mentioned his relationships with women to Doyle, only to quickly discount the seriousness of these encounters. This may simply have been Whitman's way of reassuring Doyle of the poet's "manliness" (and by extension, Doyle's own), given the heterosexual norms of the day. Another possibility is that Whitman had occasional involvements with women while in New York and at home in Washington. In such a case, Whitman may have felt the need to assure Doyle that, despite these "secondary" relationships, his affection for Pete was "primary." In this respect, although Doyle in his published remarks to Bucke and Traubel claimed that Whitman had no special relationships with women in Washington, privately Doyle told Laurens Maynard (the publisher of 
the Calamus letters from Whitman to Doyle) that "he knew of a woman in Washington with whom W. had sex relations."70 If such woman existed, she has yet to be identified.

\section{Adhesiveness}

In May 1870, Whitman cut his thumb and it became infected. Unable to perform his clerical duties in Washington, he took a short vacation to New York, bringing Pete along. ${ }^{71}$ Doyle described the visit to Bucke:

He [Walt] was a long time after me to go to New York, while his mother was alive. I asked him: "Will we stop there with your mother?" He was a little doubtful about that. We both stayed in Jersey City. ${ }^{72}$ The Whitmans lived on Portland Avenue. We took our dinner with Mrs. Whitman. We would take a bus-ride in the morning-then go to Brooklyn and have dinner. After we had had our dinner she would always say - "Now take a long walk to aid digestion." Mrs. Whitman was a lovely woman. There were just the three of us eating together. Walt and I had a week of it there in New York that time. It was always impressed upon my mind-the opera he took me to see-"Polyato." All the omnibus drivers knew him. We always climbed up to the top of the busses, our heels hanging over. (Bucke, 27)

The opera they saw was Gaetano Donizetti's Poliuto. This story about the life of the Armenian Christian martyr was performed on May 26 at the Brooklyn Academy of Music. The tenor C. Lefranc performed the title role. The American-born soprano Clara Kellogg played his wife Paolina (Odell, 8:669).

In Walt Whitman $\mathcal{F}$ Opera, Robert D. Faner noted that Whitman refers to Poliuto by name both in Specimen Days and in the poem, "Italian Music in Dakota." "Thy ecstatic chorus Poliuto." Whitman may have been as moved by Donizetti's tribulations in putting on this opera as he was by the martyrdom of Poliuto and Paolina depicted therein. Originally written to be performed in Naples in 1838, the opera was stopped by the town censors, who believed the subject matter too sacred to be paraded on the stage.

From Doyle's much-later perspective, the trip was idyllic. However, Walt's single letter to William O'Connor from Brooklyn spoke not of pleasure but of pain (from the bad hand): "It has caused me much suffering, since I have been here," he wrote (Corr., 2:98-99). Walt told William that he saw Mrs. Whitman, but he made no mention of Pete's presence.

Interestingly, this trip closely preceded a remarkable diary recording that has been much discussed by Whitman scholars. In a manuscript dated mid-June and mid-July, 1870, Whitman poured out his frustration with the Doyle relationship. The poet resolved: 
TO GIVE UP ABSOLUTELY \& for good, from the present hour, this FEVERISH, FLUCTUATING, useless UNDIGNIFIED PURSUIT of 16.4-too long, (much too long) persevered in,-so humiliating--It must come at last \& had better come now-(It cannot possibly be a success) LET THERE FROM THIS HOUR BE NO FALTERING, NO GETTING at all henceforth, (NOT ONCE, UNDER any circumstances)-avoid seeing her, or meeting her, or any talk or explanations-or ANY MEETING WHATEVER, FROM THIS HOUR FORTH, FOR LIFE. (NUPM, 2:888-889)

Oscar Cargill first surmised that 16.4 stood for Peter Doyle (the alphabetical order of his initials) ${ }^{74}$ Roger Asselineau followed this up with the observation that the "im" of him had been erased and replaced by "er" to form her (NUPM, 2:885). Whitman faults himself for making inappropriate puns, plays upon words, and sarcastic comments to "16" (NUPM, 2:887). One can imagine that the contrariness Whitman exhibited during political and philosophical discussions with O'Connor, and which led eventually to their falling-out, was present also in Whitman's relationship with Doyle. Perhaps less able than O'Connor to parry with Whitman, Doyle may have had a lower tolerance for the older man's caustic bantering. Whitman urged himself:

Depress the adhesive nature/

It is in excess-making life a torment/

Ah this diseased, feverish disproportionate adhesiveness/

Remember Fred Vaughan. (NUPM, 2:889-890)

Whitman's trip to Brooklyn in the late Spring of 1870 with Doyle, his second "Calamus Lover," resurrected memories of his first lover, Vaughan. An important motif of the "Calamus" poems written about the Vaughan relationship is a preoccupation with unrequited love. (This can be seen particularly by examining Whitman's original "Live Oak" manuscript, from which the "Calamus" poems sprang. . $^{75}$ The Summer of 1870 manuscript shows that Whitman had likewise become preoccupied that Doyle did not return his love. The MS chastized, "Cheating, childish abandonment of myself, fancying what does not really exist in another, but is all the time in myself alone-utterly deluded \& cheated by myself, \& my own weakness-REMEMBER WHERE I AM MOST WEAK, \& most lacking. Yet always preserve a kind spirit \& demeanor to 16. BUT PURSUE HER NO MORE." (NUPM, 2:887)

As already noted, Whitman's initial response to his friendship with Doyle had been to purge the "Calamus" cluster of those poems that expressed his abandonment fears. What caused these fears to arise anew? One possibility is that a change may have occurred in Whitman's physical relationship with Doyle. The 1869 correspondence suggested that Doyle was not immune to popular sexual bugaboos. As a result, Doyle may have been frightened into a period of abstinence. In the 1870 
MS, Whitman sounded like a frustrated suitor, lamenting that his "useless, undignified pursuit" of Doyle had continued far too long.

Perhaps Doyle was undergoing a period of soul-searching about his future. One can imagine that Doyle, at 27 years old, was subject to considerable societal pressure to marry. Perhaps this is what was meant by the comment made by Edward "Ned" Stewart, who in a February 25,1870 , letter to Whitman noted that Pete "is coming to his senses and thinking about settling down in life and is going to benefit by the numerous opportunities which he has" (Shively, 111). "Settling down" is typically used to convey an intention to marry. Although seemingly gay himself, Stewart was pursuing a woman in Vancouver at the time of his letter-writing to Whitman and Doyle (Shively, 111-112). Whitman described Doyle to Traubel as "a little too fond maybe of his beer, now and then, and of the women: maybe, maybe" (Traubel, 1:542-543). Whitman's first lover, Vaughan, eventually married (after his relationship with Walt had ended).

The trip to Mrs. Whitman's home with Pete, and the reminders of his shared Brooklyn home with Vaughan (Shively, 50), may have exacerbated Whitman's own desire, expressed to Doyle the previous summer, to settle down with Pete. Stewart's comments provided the reason why this dream was unattainable when he asked Walt, "How does he [Pete] \& the widow pull together now, I suppose Ile find you \& Pete in the same box when I return to Washington" (Shively, 111). Doyle, of course, was unable to establish a home with Walt because Pete's mother continued to rely upon her son for financial support.

Whatever the reason for Whitman's crisis of faith in his relationship with Doyle, it resolved itself. As Whitman was preparing to leave for New York that summer, Doyle acknowledged to Walt how deeply attached he was to him. From Brooklyn, Whitman wrote to Doyle on Saturday, July 30, "We parted there, you know, at the corner of 7th st. Tuesday night. Pete, there was something in that hour from 10 to 11 o'clock (parting though it was) that has left me pleasure \& comfort for good-I never dreamed that you made so much of having me with you, nor that you could feel so downcast at losing me. I foolishly thought it was all on the other side. But all I will say further on the subject is, I now see clearly, that was all wrong" (Corr., 2:101). A few days later, Whitman again recalled this leave-taking, describing their parting hour as if it were the scene lifted from his 1865 poem, "When I Heard the Learn'd Astronomer":

Dear son, I can almost see you drowsing \& nodding since last Sunday, going home late-especially as we wait there at 7th st. and I am telling you something deep about the heavenly bodies $-\&$ in the midst of it I look around \& find you fast asleep, \& your head on my shoulder like a chunk of wood-an awful compliment to my lecturing powers. (Corr., 2:103-104) 
Whitman remained in Brooklyn through mid-October. For the rest of his vacation, Walt's correspondence with Pete focused on mundane affairs. Pete griped regularly about his job on the streetcars. After violating some work rule, he was suspended. Walt condemned the "thin-livered cuss" Silvanus Riker, president of the Washington and Georgetown Railroad, for his ill treatment of Doyle. "Let Riker go to hell" Walt advised Pete (Corr., 2:106). The older man proposed to take Pete's mind off of his troubles: "All I have to say is - to say nothingonly a good smacking kiss, \& many of them $-\&$ taking in return many, many, many, from my dear son-good loving ones too-which will do more credit to his lips than growling \& complaining at his father" (Corr., 2:110). Walt mentioned dining with an old acquaintance, now grown rich, who lived in "a big house on Fifth avenue-I was there to dinner (dinner at 8 p.m.!)-every thing in the loudest sort of style . . . But my friend is just one of the manliest, jovialest best sort of fellowsno airs $-\&$ just the one to suit you \& me-no women in the house-he is single" (Corr., 2:109).

Assured now of Pete's affection, Whitman disregarded his resolution to shun sarcasm in his dealings with Doyle. He needled the Catholic Doyle about the Papal States' absorption by Garibaldi in the nascent Italy: "I propose to take my first drink with you when I return, in celebrations of the pegging out of the Pope \& all his gang of Cardinals \& priests $-\&$ the entry of Victor Emanuel into Rome, \& making it the capital of the great independent Italian nation" (Corr., 2:112). Whitman asked Pete to convey his love to a long list of friends, including Aunt and Uncle Nash and Father Boyle (Corr., 2:113). Aside from a single reference to his "being quite a lady's man again in my old days" after accompanying a young female neighbor to New York (Corr., 2:102), Whitman, from this time on, no longer made the suggestive references about flirting with women that had been present in the earlier years' correspondence to Doyle. Whitman wrote to William O'Connor, asking him to secure lodging for Walt at the Union Hotel, where Walt and Pete hung out after Doyle's workday (Corr., 2:115). The hotel was full, and Whitman took a room upon his return at the St. Cloud, on the corner of 9th and F streets, NW (Corr., 2:116).

The reconciliation with Doyle did not include a fulfillment of Whitman's wish to share a home with Pete. Throughout their long friendship in the District, the two men kept separate quarters. Whitman lived in various rooming houses within easy commute of the Treasury Building (15th Street and Pennsylvania Avenue, NW), while Doyle provided a home for his mother and younger siblings on M Street, Southwest, between $4 \frac{1 / 2}{2}$ and 6 th streets. 
In the spring of 1871 , Whitman joined the Doyle family as it rallied around its eldest son, patrolman Francis Michael. His arrest and incarceration on May 12 of a young boy for stealing eggs was sensationalized in the D.C. press as an egregious instance of police brutality. ${ }^{76}$ Most of the local press was not satisfied with Doyle's reprimand by the Police Board and demanded his removal from the force. Pained at the public humiliation of Peter Doyle's eldest brother, Whitman drafted an editorial in Francis Doyle's defense. Whitman commended Doyle as "an energetic officer . . . [who] bears an excellent repu[ta]tion, and served the union cause, as soldier or sailor, all through the war" (NUPM, 2:783). He lambasted the press for its "attempt to make martyrs and heroes of the steadily increasing swarms of juvenile thieves \& vagabonds who infest the streets of Washington." Although this editorial was not published, Whitman's behind-the-scenes lobbying apparently kept editors Crosby Noyes of the Evening Star and D.C. Forney of the Sunday Morning Chronicle - the District's two largest circulation newspapersfrom excoriating Doyle in print. Eventually, the other newspapers lost interest in the story. Francis Doyle kept his job on the police force.

Whitman took his annual vacation to Brooklyn in July. From there, he wrote regularly to Doyle (Doyle's letters are not extant). Whitman found Doyle in an uncharacteristically good humor about his job: "I see by your letters that every thing goes on right with you on the road" (Corr., 2:127). Whitman needled his Irish-Catholic-Southern friend in describing a brawl that had taken place in the city:

There was quite a brush in N.Y. on Wednesday-the Irish lower orders (Catholic) had determined that the Orange parade (protestant) should be put down . . . I saw a big squad of prisoners carried along under guard - they reminded me of the squads of rebel prisoners brought in Washington, six years ago-

The N.Y. police looked \& behaved splendidly - no fuss, few words, but action - great, brown, bearded, able, American looking fellows, (Irish stock, though, many of them)." (Corr., 2:126-127)

The old man softened this jab with an affectionate sign-off, "Love to you, my dearest boy" (Corr., 2:127).

Later that year, Pete and his family were shocked by the murder of Francis Michael Doyle. On the afternoon of December 29, 1871, Policeman Doyle was attempting to serve a warrant to search the house of John and Maria Shea, who were fences for stolen goods. Mrs. Shea shot him in the chest with a Remington-type six-shooter, killing the policeman immediately. Whitman attended the funeral for Francis, held on New Year's Eve (Corr., 2:148-149). According to the report in the 
Evening Star, thirty of Doyle's fellow officers escorted the policeman's remains to a grave in Washington's Congressional Cemetery.

\section{Working on the Railroad}

Doyle left his job as streetcar conductor the following year. He "went on the Pennsylvania Railroad" in 1872 (Bucke, 23). The Pennsylvania Railroad, through its Baltimore and Potomac Railroad subsidiary, opened its line from Baltimore to Washington, D.C., on July 2, $1872 .{ }^{77}$ Doyle started on the railroad as a brakeman, according to the occupational listing for Doyle in the 1873 Washington city directory.

In the days before the widespread use of automatic airbrakes, a train necessarily was braked by hand. ${ }^{78}$ The brakeman rode on the top of the freight or passenger car where he could observe the terrain and quickly respond to the need for putting on, or releasing, the brakes. He did this by turning a wheel on the roof which was connected to a rod that, in turn, applied friction to the train's wheels. Each car had its own brake, and a brakeman was responsible for braking several cars in a long train. To do this, the brakeman had to jump across and run the length of each of several cars to apply the brakes in good time. In bad weather anytime, but especially during the cold winters when the roofs were covered with snow and ice, this job could be quite dangerous. A misstep could easily result in a brakeman's falling off the train or between the cars.

Another feature of the brakeman's job was "going back to flag." When a train was stopped on the tracks, the brakeman on the rear car had to take his red flag or lantern and go back down the track a half mile or more to give the "stop" signal to the engineer of any train that may be following. In performing this job, the brakeman faced the risks of over-exposure in frigid temperatures and being hit by a train that failed to heed his stop signal.

A brakeman was also responsible for "coupling," that is, joining together, the separate cars of a train before it set out on its assigned run. Coupling required the brakeman to lift the link in one car and guide it into the opening of the approaching car. Although railroad regulations specified that the brakeman stand beside the tracks and perform the task by the use of a short stick, more typically the brakeman chose to couple the cars by hand as he stood on the tracks in between the cars. This exposed him to the risk of having his hands or entire body crushed by the approaching car should he make the slightest mistake in the task's execution.

Given such risks faced by a railroadman of that day, it is no wonder that Whitman described Doyle's work, in a letter to Ellen O'Connor, as "his dangerous post on the Baltimore \& Potomac RR" (Corr., 2:230). 


\section{Nursing Walt}

On Thursday evening, January 23, 1873, Whitman suffered a stroke while reading in the Attorney General's offices at the Treasury Building (Corr., 2:192). Spelling nursing duties with Ellen O'Connor and Charley Eldridge, Peter Doyle attended Whitman regularly during the next several months. Doyle's custom was to stop by in the late afternoon, before his evening shift on the railroad. Accompanying a gift copy of Specimen Days given to Doyle in 1883, Whitman recalled Pete's labor of love on the poet's behalf during this difficult time:

Pete do you remember . . . during my tedious sickness and first paralysis ('73) how you used to come to my solitary garret room and make up my bed, and enliven me and chat for an hour or so-or perhaps go out and get the medicines Dr. Drinkard had order'd for me-before you went on duty? (Bucke, iii)

Whitman's mother wrote approvingly to Walt of Pete's ministrations on her son's behalf: "i thought of peter. $i$ knew if it was in his power to be with you he would and cherefully doo everything that he could for you" (Corr., 1:193n). By mid-February, Walt was making short jaunts outside his room, "convoyed" by Pete or Eldridge. Pete gave Whitman a shillelagh to lean upon as he walked (Traubel, 5:228).

In February, Whitman received the sad news that his brother Jeff's wife, Mattie, had died. Toward the end of March, Whitman resumed work at the office. He took the precaution, however, of writing a will, on May 15, 1873 (NUPM, 2:917-919). He left most of his estate to his mother, in trust for the care of his feeble-minded brother, Edward. Token sums were also given to his surviving sisters and brothers. Peter Doyle was the only non-family member listed in the will. Walt wrote, "I wish Eighty-Nine Dollars paid to Peter Doyle - that sum being due to him from me. I also will to him my silver watch. Appleton-Tracy movement, hunting-case. I wish it given to him with my love."

That spring, Walt had begun to receive disturbing reports of his mother's ill health. He visited her in Camden, New Jersey, where she was then living with her son, George, and his wife. He arrived in time to be present at her death on May 23. Walt returned to Washington on June 2, staying at the home of Mr. and Mrs. J. Hubley Ashton (one of the Attorneys General that Whitman served under) at 12th and $\mathrm{K}$ streets, NW (Corr., 2:222). Whitman did not stay long with his Washington friends. Within two weeks, he had moved in with George in Camden to convalesce, hoping the move would be temporary.

Meanwhile, Pete was unhappy with his railroad job. He asked Walt for help in securing a job as a letter carrier. Whitman wrote back enclosing a letter to the Postmaster (Corr., 2:224). He also asked Crosby Noyes, editor of the Evening Star, to write a line on behalf of Pete's 
application. Unfortunately, the job fell through, as Walt remarked in a July 7 letter to Pete:

I rec'd your letter telling me you was too late to get any chance for the letter carrier's position $-\&$ about Mr. Noyes' friendliness-Are things just the same, as far as you and your crew are concerned? I think about you every night - I reproach myself, that I did not fly around when I was well, \& in Washington, to find some better employment for you - now I am here, crippled, laid up for God knows how long, unable to help myself, or my dear boy-I do not miss any thing of Washington here, but your visits - if I could only have a daily visit here, just as I had there. (Corr., 2:227)

Although Whitman wished to return to Washington, he never recovered the strength to do so. With Walt in Camden, Pete relied more on his friendship with Parker and Wash Milburn. The men worked in the family drugstore. Whitman was eager to be kept informed of the men's activities. He had spent many pleasant afternoons quenching his thirst with the Milburns' "Unrivalled Polar Soda Water," at their shop opposite the Treasury Building. Pete also became better acquainted with Charles Eldridge and Ellen O'Connor, as the erstwhile nurses shared their news of Walt with one another. Doyle kept up an acquaintance with Crosby Noyes. He also kept Walt posted on the fortunes of Louis Fitzgerald Tasistro, an Irish-born actor and journalist for whom Whitman solicited financial contributions in 1872 .

Walt was disappointed that Pete was unable to pay a Christmas 1873 visit. His spirits brightened in January 1874, however, when Pete told him of his plans to seek the position of baggagemaster on the through New York train, with the placement being in Philadelphia (Corr., 2:265). When the appointment did come through in April, however, it was for the Washington/Baltimore segment only (Corr., $2: 294,296)$. Pete sought out William Colein, an engineer in the fire room at the Treasury Building, who had bumped into Walt on a Philadelphia streetcar (Corr., 2:280). In March, Pete and Walt mourned the death of Parker Milburn, who died of pneumonia at the age of thirty-eight (Corr., 2:283).

At the end of May, 1874, Pete finally made it to Camden. He took the horsecars from the Pennsylvania Railroad station in Philadelphia, to the Market Street ferry, and then across to Camden for the final leg by foot up to Stevens Street. As Walt wrote to Nelly O'Connor: "Peter Doyle has ... paid me a short visit of a couple of days - the dear, dear boy $-\&$ what good it did me!-(Unfortunately it was, however, at a time when I was feeling almost at my worst)" (Corr., 2:304).

\section{By the Banks of the Delaware}

In July, 1874, Walt had to break the unpleasant news that Camden was his home for good: 
I have been discharged from my clerkship in the Solicitor's office, Treasury, by the new Solicitor, Mr. Wilson.

I think of laying up here in Camden. I have bought a cheap lot $-\&$ think of putting up a little two or three room house for myself. My darling son, you must not be unhappy about me-I hope \& trust things may work so that we can yet be with each other, at least from time to time-\& meanwhile we must adapt ourselves to circumstances. You keep on, $\&$ try to do right, $\&$ live the same square life you always have, $\&$ maintain as cheerful a heart as possible $-\&$ as for the way things finally turn out, leave that to the Almighty-Pete, I shall want you or Mr. Eldridge to see to the sending on here of my boxes at Dr. Whites. (Corr., 2:308)

Pete continued to keep the house on M Street, Southwest, for his mother, brother Edward, and sister Margaret. As they gained employment, the younger Doyles made their own financial contributions to the house kitty. Edward worked at the trades of laborer, conductor, fireman, and building engineer. In 1875, sister Margaret Doyle left the house on M Street to marry John G. Berckmann. Berckmann was a cabinetmaker who joined forces with a designer, Charles Albert (Abby) Rappee, to start their own establishment. Berckmann and Rappee supplied furniture for the Capitol, the White House, and the old Supreme Court chambers. Margaret and John Berckmann had four children: Mary Catherine (Mrs. McLaughlin's mother); Katherine; William E.; and Henrietta. Three of their grandchildren-Mary McLaughlin and Catherine Rippard of Washington, D.C., and Jean Timlin of Sandwich, Massachusetts-are still living.

Whitman had been promising a visit to Pete in Washington for some time and finally made plans to come down in November 1875 . He wrote Pete that he would be taking the Pennsylvania Railroad's noon limited express from West Philadelphia to Washington on Monday, November 8 (Corr., 2:342). Pete met him at the Baltimore and Potomac station. While in Washington, Walt stayed with Pete's uncle and aunt, Michael and Ann Nash, in their home by the Navy Yard (Corr., 2:342). ${ }^{79}$ No doubt, Walt reacquainted himself with the old streetcar route that he had ridden so often in the past, alongside Pete, the conductor.

Whitman's stay lasted about two weeks. In addition to his visits with the Doyle family members, Walt took time to see Ellen O'Connor and other friends. Reminded anew of the pleasurable times spent in Washington, Walt endorsed the efforts of a group of supporters who petitioned the Treasury Secretary on November 15 to appoint Whitman to a position in the Department. Although Secretary Benjamin Bristow responded favorably, nothing came of this attempt to get Walt back in Washington on the government payroll (Corr., 2:342n). ${ }^{80}$ On November 17, Whitman went to Baltimore to appear at the dedication of a memo- 
rial to Edgar Allan Poe. Pete probably arranged to convoy Walt there via the B\&P Railroad.

The extant correspondence from Walt to Pete drops off sharply in 1876. Pete faithfully sent Walt the Washington papers. Whitman acknowledged them with a postcard reply. The falling-off of letter writing to Pete coincided with Whitman's growing involvement with Harry Stafford. Stafford was a twenty-something office clerk for the Camden New Republic (Corr., 3:3). Three years after Walt had left Washington and the daily comradeship that Pete provided, he was ready to begin what Edwin Haviland Miller termed "the last of the intense 'Calamus' friendships" (Corr., 3:9). Now Harry was to be Whitman's "darling boy." Occasionally, however, there were flashes of the old feeling for Pete, as expressed in this December 1876 letter from Walt:

I ought to have written to you before-but I believe lazy \& listless fits grow stronger \& frequenter on me as I get older $-\&$ then I dont do anything at all, especially just the things I ought to do-But I often, often think of you, boy, \& let that make it up. I certainly am feeling better this winter-more strength to hold out, walking or like, than for nearly now four years - bad enough yet, but still decidedly better-(My loving boy, I underscore the words, for I know they will make you feel good, to hear). (Corr., 3:67)

Doyle responded to Walt's sentiment by sending on a monetary gift. Walt insisted on treating it as a loan, to be paid back "when I am flush" (Corr., 3:71). He gave Pete "that arm chair (with the broken arm) I left at Mrs Nash's . . . you take the chair home for you as a new year's present, \& for your mother to sit in, \& you afterwards-you know I used the chair for a year, \& if I recollect right, it is a good strong one, though plain" (Corr., 3:71-72).

In the summer of 1877, Whitman wrote from Anne Gilchrist's Philadelphia home and extended an invitation for Doyle to join him there. Pete evidently was unable to accept this hospitality. (Neither Whitman nor Edward Carpenter, Walt's house guest from England who was staying with him at the Gilchrists', mentioned a visit by Doyle.) For the first time, Walt told Doyle of the Stafford farm, but he did not mention Harry. Whitman wrote, "I spend most of my time down at an old farm down in Jersey where I have a fine secluded wood \& creek \& springs, where I pass my time alone, \& yet not lonesome at all (often think of you, Pete, \& put my arm around you \& hug you up close, \& give you a good buss-often)" (Corr., 3:87).

Walt expressed his desire to visit Washington in the fall of 1877. When this passed and he hadn't gone, he talked about going in 1878. As it turned out, after the trip in 1875, Whitman never again visited the District (Corr., 3:115n).

In January, 1878, Whitman sent Doyle a copy of Autumn Rivulets and a West Fersey Press story about the poet. ${ }^{81}$ Doyle sent back a 
thank-you on January 20,1878 , in which he teased, "If the Spirit moves me, I will give you my opinion of the book when I have read it carefully, that is if you should care to know my opinion" (Shively, 114).

Whitman wrote to Doyle on April 29, 1879 (DBN, 1:143), perhaps to solidify their plans for a get-together that Spring. (The two met, but it's unclear whether the reunion occurred in Camden or in New York City, where Whitman had gone to present his Lincoln lecture on April 14 (Corr., 3:158-159). In November, Whitman wrote a long letter from his brother Jeff's home in St. Louis. He told Pete all about his Western sojourn "out to the Rocky Mountains and Colorado (2000 miles)" (Corr., 3:167).

The following year, Whitman sent Doyle complimentary tickets to the poet's April 15, 1880, "Death of Abraham Lincoln" lecture. It was held in Philadelphia's Association Hall $(D B N, 1: 178)$. (There's no record of whether Pete attended.) A few days after the lecture, Walt enclosed a copy of the April 16 issue of the Camden Post that contained an account of the oration, written by Whitman himself $(D B N, 1: 178)$. Presumably, Doyle, the actual eye-witness to Lincoln's assassination, critiqued the poet's simulation of that fateful evening.

\section{Comrade Meets Disciple}

In the summer of 1880 , Peter Doyle made the acquaintance of Richard Maurice Bucke. The Canadian physician, who played a major role in the promotion of Whitman and his work during and after the poet's lifetime, was then gathering materials for a biography of Whitman. Bucke had sent a circular to Walt's friends and acquaintances soliciting information about his subject. Through Doyle, Bucke unearthed a motherlode of correspondence. Bucke described his good fortune in a June 6, 1880, letter to his friend, Harry Buxton Forman:

I returned the day before yesterday from New York, Phila, and Washington and Walt came home with me-he will spend a large part of the summer here and we will probably go to Montreal, Ottawa, etc. together before the summer is over . . . While I was away I worked like a beaver collecting materials, and putting myself in a position to collect materials for my work on Walt . . . I have called upon and become pretty well acquainted with a number of friends of Walt's and have got promises from quite a number of them of assistance. In the way of answers to my circular (which I enclose) and in other ways, in particular, I found a man in Washington,-he is a baggageman on the Baltimore \& Potomac R.R. who has been an intimate friend of Walt's for 15 years - he and Walt love one another (as far as I can make out) much more than father and son can love one another-this man has had letters from Walt for 15 years, and of course saved them all, - he had a trunk full of them, these letters I hope to get - he will send them to me and I shall keep them as long as I like-I hope to make a long chapter of extracts from them. ${ }^{82}$ 
Apparently, Doyle sent on the letters, for Bucke wrote to Forman on September 17 that he was in possession of "a series of letters written by Walt to a young man, one of his most intimate friends ... The letters I speak of are wonderful, they are extremely simple, but have an extraordinary charm which I could not give you any idea of" (Lozynsky, 75). In the same letter, Bucke revised his plan for using the letters in the current biography, thinking it better to reserve them for "use in subsequent Eds; - Should I live after Walt leaves us." (The biography was published in June 1883 and did not mention Doyle, nor the letters Whitman wrote to him. ${ }^{83}$ Bucke held onto the letters, however, and shared their contents with sympathetic readers.)

From Ontario, Whitman wrote to Doyle twice; in June, at an address in lower Manhattan $(D B N, 1: 198)$ and again at the end of July. Doyle joined Whitman and Bucke in Niagara Falls on September 28 at the tail end of Whitman's Canadian visit (Corr., 3:187). Walt and Pete stopped a day and night there. For their return trip, they boarded "an easy comfortable palace car \& went on like a streak through New York and Pennsylvania-got into Philadelphia after 11 at night ... but the city looked bright \& all alive, \& I felt as fresh as a lark," as Walt described the trip in a letter to Thomas Nicholson, an attendant at Bucke's Asylum for the Insane in London, Ontario (Corr., 3:189).

In June, 1883, Whitman gave Pete a copy of his Specimen Days and Collect (it was probably the second edition that had just been published by McKay in Philadelphia). In a note to Doyle on the fly leaf of the autographed copy, Whitman reminisced about their shared Washington days:

Pete do you remember-(of course you do-I do well)-those great long jovial walks we had at times for years, (1866-'72) out of Washington City - often moonlight nights, 'way to "Good Hope"; or, Sundays, up and down the Potomac shores, one side or the other, sometimes ten miles at a stretch? Or when you work'd on the horse-cars, and I waited for you, coming home late together-or resting and chatting at the Market, corner 7th street and the Avenue, and eating those nice musk or watermelons? . . . Give my love to dear Mrs. and Mr. Nash, and tell them I have not forgotten them, and never will. (Bucke, iii)

In October 1883, Pete's uncle, Michael Nash, died. According to the report in Crosby Noyes's Washington Evening Star, Nash-"one of the best known citizens in the District"-died on October 14 "at his home in East Washington from the effects of injuries received in a fall about a week ago. Mr. Nash was throwing some wood in the cellar, and, making a misstep, fell down the cellar-way, breaking several ribs and sustaining injuries to his head." The members of the Oldest Inhabitants attended the wake "in a body" at Nash's L Street home. From there, they proceeded to St. Peter's Church on Capitol Hill for the funeral mass, and finally to the graveside in Congressional Cemetery. Whitman made a note of Nash's burial in his daybook ( $D B N, 2: 231)$. 
On December 7, 1883, Pete visited Whitman at his Camden home $(D B N, 2: 325)$. He sought Whitman's help in procuring a job for his brother, Edward, at the Treasury Building in the District. Whitman wrote to William O'Connor, who was then Assistant General Superintendent of the Treasury's Life-Saving Service (Freedman, 278), to enlist the insider's support:

A young workingman \& engineer, Edward Doyle, (brother of my dear friend Peter D.) may call on you, before long, to see what chance if any for employment. He is healthy, strong, intelligent for a laboring man-no bad habits-single-hails from Washington. (Corr., 3:358)

The poet received another visit from Doyle on June 4, 1884, a day after Doyle's forty-first birthday, and six days after Whitman's sixtyfifth.

\section{A Philadelphia Home for Pete}

Pete's mother, Catherine, died on May 24, 1885 (DBN, 2:357). Mrs. Doyle was buried beside her son, Francis Michael, in Congressional Cemetery on June 3, Pete's birthday. ${ }^{84}$ The day after the burial, Pete visited Walt in Camden. Whitman, whose own mother's death anniversary was within a day of Catherine Doyle's, provided whatever consolation he could to his dear friend ( $D B N, 2: 158)$.

With the death of Catherine Doyle, Pete's primary emotional tie to D.C. ended. Thereafter, his permanent address was Philadelphia. In actuality, Pete had probably relocated semi-permanently in Philadelphia before then. The Philadelphia city directory began to consistently list "Peter Doyle, baggagemaster," in 1884, although there is a listing for a Peter Doyle, brakeman, as early as 1880 . Whitman noted a Philadelphia address for Doyle as early as 1883 , alongside his Washington address $(D B N, 2: 322)$. The Washington, D.C., directory listed Doyle regularly until 1885 but not afterward.

There is no extant correspondence between Doyle and Whitman at all between 1881 and 1886, although Whitman's daybook does indicate that the two corresponded occasionally during this period. Perhaps this is because the bulk of the surviving Whitman letters are those that Doyle entrusted to Bucke in 1880, and the letters following this date (typically postcards?) were not preserved. Equally likely is that Doyle and Whitman saw one another with some frequency, thus alleviating the need for regular correspondence (Johnston \& Wallace, 147). 
In Philadelphia, Pete joined the city lodge of the Benevolent Protectorate Order of Elks. The Philadelphia lodge, chartered on March 12, 1871 , was the second to be organized by this secret fraternity that began in New York in $1868 .{ }^{85}$ During the next several decades, the Elks grew rapidly. By the time of Doyle's death in 1907, there were over 1,000 lodges in as many cities.

The Elks was founded by actors. They sought to build a national fraternity that would create a sense of "home" in different locations for the benefit of its traveling members. Originally, many of the lodges had sleeping accommodations for out-of-town members. This aspect appealed to railroad men like Doyle, who were well represented in the Elks' membership.

Gustave Wiksell testified to the importance Doyle placed on his membership in this fraternity: "Fellowship was Pete's faith, and the Elks, to whose organization he gave time and money, represented his principles and embodied his ideas of practical service." The lodge was housed on Arch Street, two blocks from Pete's last address. ${ }^{86}$ Could it have been Doyle's involvement with this organization, whose membership included such leading citizens as the actor Edwin Booth and statesman Theodore Roosevelt, that caused Whitman to remark about Doyle that "For years past Pete has been whirled among the sophistications" (Johnston \& Wallace, 152)?

Peter Doyle was also a member of the United Confederate Veterans. He belonged to the Robert E. Lee Camp No. 1 in Richmond, Virginia. ${ }^{87} \mathrm{He}$ joined the camp on June 13,1890 , upon the recommendation of Thomas F. Moseley, a former comrade-in-arms from the Richmond Fayette Artillery (RFA), and James T. Ferreter, formerly of Pegram's Battalion, Letcher Battery. Other RFA veterans in the camp included Robert B. Chandler, Charles Clinely, Robert I. Fleming, and John T. Hartman. The camp listed Doyle on its roster through Pete's death in 1907 , and thereafter in memoriam. ${ }^{88}$

The United Confederate Veterans was the Rebel counterpart to the Federals' Grand Army of the Republic. The Lee camp, to which Doyle belonged, was founded on April 18, 1883, and had as its original purpose the raising of funds for an Old Soldier's Home in Richmond. ${ }^{89}$ Support for the idea of a group devoted to the interests of those men who had fought for "The Lost Cause" was exceedingly strong throughout the Southern states. By 1898, the Lee camp claimed to have spawned more than eleven hundred camps, with an estimated one hundred thousand member-veterans.

Although nominally a Catholic, Pete was not a regular church-goer. As Doyle admitted to Bucke and Traubel in 1895, "I have not been to 
church in so many years that I would not know what to do there" (Bucke, 28).

\section{The Old Man's Decline}

Apparently, Doyle and Whitman kept in touch up until early 1889. The last certifiable contact between Whitman and Doyle was on June 15, 1888, two weeks after Doyle's forty-fifth birthday and Whitman's sixty-ninth. Walt mentioned in a letter written to Bucke that Pete had been to visit that day (Corr., 4:174). In January 1889, Whitman made a remark to Traubel which suggested that Walt was still in contact with Doyle. Whitman urged Traubel to seek out the railroadman: "You and Pete would get to be great chums . . . you, Horace, must particularly make it your point to come in relations with him" (Traubel, 1:542-543). By May, 1889, however, it is clear that Whitman himself had not seen Doyle for some time. "I wonder where he is now? He must have got another lay," Whitman lamented to Traubel (Traubel, 5:228).

By the summer of 1891, Whitman seemed resigned to Pete's absence. When Traubel inquired of Doyle's current whereabouts, Whitman groused, "He has not been here for some years. He is a bird of passage-always on the wing. He has not been to see me as often as I like. I would not know how to reach him now."90

When J.W. Wallace of Bolton, England, traveled to Camden to visit Whitman, he asked to see Doyle. Wallace's interest in Doyle was piqued by his study of Whitman's letters to Pete, shown to him by Bucke. "I read all and copied some of the letters to Doyle, which Bucke has, and I am interested to meet a man for whom Walt demonstrated such an affection," Wallace explained to Traubel (Traubel, unpublished, October 15, 1891). Whitman was obliged to tell his English visitor, "I don't know where he is. I have not known for two years . . . I should like to know where Pete is as I am rather uneasy about him. The cars used to come to Philadelphia, and he came here every week ... I fear something must have happened to him" (Johnston \& Wallace, 146-147). Ellen O'Connor had told Traubel that Pete was living in Baltimore, to which information Walt responded, "Oh! Well, it was entirely new to me. I did not know of the change! The noble Pete! I hear but little from him. Yet that is not wonderful either-I never did hear much." Whitman went on to describe Pete as "a mechanic-an instance out of the many mechanics I have known who don't write, won't write-are apt to get mad as the devil if you ask them to write. But of course I always humored Pete in that. It was enough for me to know him (I suppose, too, for him to know me). And I did most of the writing. He is a train-hand: like all the transportation men, necessary wanderers. Wallace wants to see him. You must put your heads together 
and see if it can't be arranged" (Traubel, unpublished, October 16, 1891). Apparently it couldn't be arranged, and Wallace's published diary of the Camden visit simply recorded his disappointment in not being able to meet Doyle.

Whitman spent the last year of his life making the final revisions to Leaves of Grass. In the death-bed edition, published in 1891 and dated 1892 , Whitman inserted the following recollection in "Specimen Days," as a tribute to his long friendship with Pete:

The roads. - A great recreation, the past three years, has been in taking long walks out from Washington, five, seven, perhaps ten miles and back; generally with my friend Peter Doyle, who is as fond of it as I am. Fine moonlight nights, over the perfect military roads, hard and smooth-or Sundays-we had these delightful walks, never to be forgotten. The roads connecting Washington and the numerous forts around the city, made one useful result, at any rate, out of the war. ${ }^{91}$

On Christmas Eve, 1891, Whitman prepared his last will and testament. In it, he reiterated the desire expressed in his 1873 will that Peter Doyle be given his silver watch (NUPM, 3:1285). Unlike that earlier will, however, Doyle was only one of a host of friends and family members to whom Whitman bequeathed some remembrance, including Harry Stafford, who was given Walt's gold watch. On New Year's Day, 1892, Whitman had a change of mind about the bequests. He summoned Traubel to his bedside and told him, "Horace, my will is not yet right: it does too much in some directions, too little or nothing in some others" (Traubel, unpublished, January 1, 1892). Traubel brought Thomas B. Harned, Whitman's attorney, over to draw up a codicil to the will. Among other changes, he bequeathed his gold watch to Traubel and gave the silver watch to Stafford. Peter Doyle, who had been so absent from Walt's life during these last few years, was removed from the will (NUPM, 3:1287).

Apparently, Doyle did reconnect with Whitman sometime before the poet's death. ${ }^{92}$ Anne Traubel recalled that "When Walt was no longer able to see friends, Pete in his despair would come up to learn such details as I may have been able to give him."93 Doyle had an opportunity to tell Whitman the reason for his negligence:

I know he wondered why I saw so little of him the three or four years before he died, but when I explained it to him he understood . . . It was only this: In the old days I had always open doors to Walt - going, coming, staying, as I chose. Now, I had to run the gauntlet of Mrs. Davis and a nurse and what not. Somehow, I could not do it. It seemed as if things were not as they should have been. Then I had a mad impulse to go over and nurse him. I was his proper nurse-he understood me-I understood him. We loved each other deeply. But there were things preventing that, too. I saw them. I should have gone to see him, at least, in spite of everything. I know it now. I did not know it then, but it is all right. Walt realized I never swerved from him-he knows it now-that is enough. (Bucke, 32-33) 
Whitman died on March 26, 1892. Pete came by to view the body, according to Whitman biographer Henry Bryan Binns. ${ }^{94}$ The policeman guarding the door almost turned Doyle away, however, before one of Whitman's friends recognized Doyle and let him in. Traubel's notes made on the day of Walt's funeral state:

Someone was sure Pete Doyle was seen somewhere in the crowd, but I saw nothing of him till we had got to Harleigh, when he was pointed out to me (by Burroughs) up the hill, twirling a switch in his hand, his tall figure and big soft hat impressively set against the white-blue sky. (Returning, we stopped our carriage, seeing him on the road, leisurely walking, and Burroughs called him, he running up, shaking hands all around and calmly talking some to us, as to himself and Walt. Is on a Providence line of railroad. I told him of Mrs. O'Connor. Seemed immobile, not greatly moved by the occasion, yet was sincere and simple and expressed in his demeanor the powers by which he must have attracted Walt.) (Traubel, unpublished, March 28, 1892)

After Walt Whitman's death, Horace and Anne Traubel continued their friendship with Peter Doyle. Anne Traubel described Doyle to Oscar Lion (the noted collector of Whitman materials) as "a fine, sensitive person. I became warmly attached to him. I enjoyed his visits. He enjoyed being with us." Doyle was a subscriber to the Conservator, the journal edited by Horace and Anne and their daughter, Gertrude.

Horace introduced Pete to Traubel's lover, Gustave Percival Wiksell. ${ }^{95}$ This meeting resulted in a close friendship between the three men. Wiksell recalled that "Traubel and I never lost sight of Pete for long at a time. Traubel would see him in Philadelphia, where he lived, and I would see him in Boston. Often, when Traubel was in Boston, we would go to Pete's haunts together, talking, jollying, with him as he ate his dinner or drank his beer." 96

\section{The Publication of "The Pete Letters"}

As mentioned, Bucke held onto the letters written by Whitman to Doyle and shared their contents with interested persons. One of those to whom Bucke gave access was John Addington Symonds. The British scholar mentioned these letters in his study of Whitman, which was published in $1893 .{ }^{97}$ The friendship portrayed in this correspondence assured Walt and Pete a place in Symonds's pantheon of male lovers, alongside David and Jonathan, Achilles and Patroclus, and Orestes and Pylades. John Burroughs responded warmly to Symonds's study. In a May 12, 1893, diary entry, Burroughs wrote:

This day Symonds' book on Whitman came to me, and I nearly finished it at odd intervals, sitting in the summer-house and looking out into the lovely world. It is a strong book and will play its part in settling Walt's fame. I see in it little to except to. The hearty endorsement of the sexual poems quite surprised me. Symonds acknowledges his own 
debt to Whitman in strong, eloquent words ... I could have wept over the book, thinking of Symonds just dead, and his words ringing so clear and eloquent; and of Walt, whom my soul so loved. ${ }^{98}$

Partly in response to the interest generated in the letters from Symonds's description of them, Bucke resurrected his scheme to publish Whitman's letters to Doyle. Anne Traubel recalled:

When the publication of these letters was discussed, Horace said that Peter Doyle, as the remaining factor in their existence, should certainly appear in their production. Dr. Bucke was well pleased when Horace said he would talk to Pete about the letters. Dr. Bucke was present at the interview and included it in his introduction. ${ }^{99}$

This conversation with Doyle took place in May, 1895 . Whether by Bucke's design or mere coincidence, the interview was conducted in the same month that Whitman's admirer, Oscar Wilde, was sentenced in London to two years hard labour because of his own romantic relationship with a younger man, Lord Alfred Douglas.

Bucke solicited the help of J.W. Wallace and Edward Carpenter to find an English publisher. Carpenter expressed his enthusiasm for the work in a January 16, 1896, letter to Bucke, "It is lovely-most excellent." ${ }^{100}$ Regretfully, he did not think "there is the least chance of any London publisher taking it-both on account of the unheard of nature of the contents and the doubtfulness of the monetary speculation." Carpenter ended with a suggestion that the proposed title, Calamus, "ought to be kept for the original poems. Some compound, like Calamus-Leaves perhaps might do-or wd. Leaves of Friendship be better?"

The letters were published in 1897 under the title Calamus, A Series of Letters Written During the Years 1868-1880 by Walt Whitman To A Young Friend (Peter Doyle) by Boston publisher Laurens Maynard. Again, whether by design or accident, the book's publication coincided with Oscar Wilde's release from Reading Gaol in May 1897.

Reviews of the Calamus letters were decidedly mixed. A commentary in The Nation's July 1, 1897, edition was sorry that there was so much of Whitman and so little of Doyle in the book:

There are quite enough of Whitman's letters; half as many would have been equally significant. But it would be very interesting to know how 'Pete' 'kept up his end' of the correspondence, and we have no means of knowing. In his introduction Dr. Bucke reports an interview with him eleven pages long, from which it would appear that his letters may have been as good as Whitman's or better. It is one of the pleasantest accounts of Whitman we have had.

Whitman's letters were dismissed by The Nation's reviewer for "their unvarying puerility ... The letters are such as might have been written 
by some illiterate person interested only in the most common-place affairs."

Henry James, writing for the April 16, 1898, issue of Literature magazine, also praised the Doyle interview. He declared Doyle's account of his first meeting with Whitman on the horsecars "the most charming passage in the volume." James acknowledged that Whitman's letters lacked literary flair, but he liked them precisely for that reason:

There is not even by accident a line with a hint of style-it is all flat, familiar, affectionate, illiterate colloquy ... Whitman wrote to his friend of what they both saw and touched, enormities of the common, sordid occupations, dreary amusements, undesirable food; and the record remains, by a mysterious marvel, a thing positively delightful. If we ever find out why, it must be another time. The riddle meanwhile is a neat one for the sphinx of democracy to offer.

Ellen O'Connor Calder (the widow of William O'Connor married Albert Calder, of Providence, Rhode Island, in 1892) wrote Bucke to tell him 'how deeply \& immensely interested I was in 'Calamus,'those days are all very vivid in my memory." 101 She also sent along a contrary opinion published in her local newspaper, the Providence Sunday fournal, on July 18, 1897. The reviewer expressed "Our surprise that these stupid and commonplace letters from the old man to 'a young friend' should be thought worthy of putting into print, even by the most besotted follower of the Whitman cult. There is absolutely nothing in them that any half-educated person might not have written in a private letter."

Modern-day readers of the Calamus book of Whitman's letters to Doyle, and of Pete's account of their times together, find the book remarkable for its frank acknowledgement of the romantic nature of the attraction between Whitman and Doyle. At the same time, such readers are often cautioned about projecting modern sensibilities onto 19th Century correspondence. It is interesting, then, to find that reviews of the Calamus book, written shortly after its initial publication, endorse the late-20th Century view that this is indeed a book of love letters. For example, the following review appeared in The Critic on January 1, 1898:

The publishing of the letters addressed by Whitman to Peter Doyle is justified by the fact that they throw all the light that is needed upon the poet's friendships with younger men, and upon that section of "Leaves of Grass" called "Calamus" in which he celebrates "the manly love of comrades." The sentiment in question, depending on a semi-physical attraction, is common among boys, young men of the working class, who can be considered as grown-up boys, and, as we are told by travellers, among savages. These letters show Whitman to have been one of the few in whom this feeling lives on into mature years; he seems to have been always attracted by, and attractive to, young men. The recipient of these letters was a young Confederate soldier, who, being paroled in 
Washington, became a car-conductor, and in that capacity first encountered Whitman, whose habit of conversing at every opportunity with men of that class is well known.

The "Calamus" book of letters was forbidden reading in the household of Peter's sister, Margaret, according to her granddaughter, Mary. Thereafter, Pete was "the Black Sheep" of the family. Considering the prejudices of the day against gay men, Peter Doyle deserves considerable credit for the courage he showed in agreeing to the publication of this revealing correspondence.

\section{Pete's Last Years}

The "Pete letters" gave Doyle a warranted celebrity among Whitman's friends and followers. He was a welcome guest at the gatherings of the Walt Whitman Fellowship, the group founded in 1893 by Whitman's friends. According to the minutes of the Fellowship's May 31, 1899, meeting at New York's Hotel St. Denis, Peter Doyle was present at the afternoon session. He heard Alma Calder Johnston speak on "Walt Whitman and Woman," Thomas B. Harned lecture on "Whitman and Physique," and Laurens Maynard give "A Few Notes on Whitman and the New England Writers." 102 At the evening's dinner, Doyle gave a brief speech, as did John Burroughs, John Swinton, John H. Johnston, and Horace Traubel.

H.B. Binns sought out Doyle as he prepared his biography of the poet (Binns, x). Included in Binns's work, published in 1905, was a photograph of Pete at fifty-seven years old-well-dressed, mustachioed, and still strikingly handsome (see Figure 4; and Binns, 233).

Peter Doyle died on Friday morning, April 19, 1907, at St. Joseph's Hospital in Philadelphia of uremia, a disease of the kidneys. He was sixty-three years old. His brother Elks provided a wake at the Philadelphia lodge house. His sister, Margaret, arranged for a Requiem High Mass at St. John's Catholic Church in Philadelphia. Peter Doyle was buried at Washington's Congressional Cemetery. By then, the cemetery held the remains of Pete's aunt, Ann Nash, who died on March 24, 1891, and his brother Edward, who died on July $10,1900,{ }^{103}$ in addition to Pete's mother, uncle Michael, and brother, Francis. Doyle did not have a will, but his estate was valued intestate at close to $\$ 5,000$. $^{104}$

Word of Pete's death spread through the Whitman Fellowship. At the annual meeting on May 31,1907, Wiksell gave a eulogy. Traubel reprinted it in the September issue of The Conservator. When John Burroughs was told of Pete's death, he said it was "almost like losing Walt anew" (Barrus 1:82). 


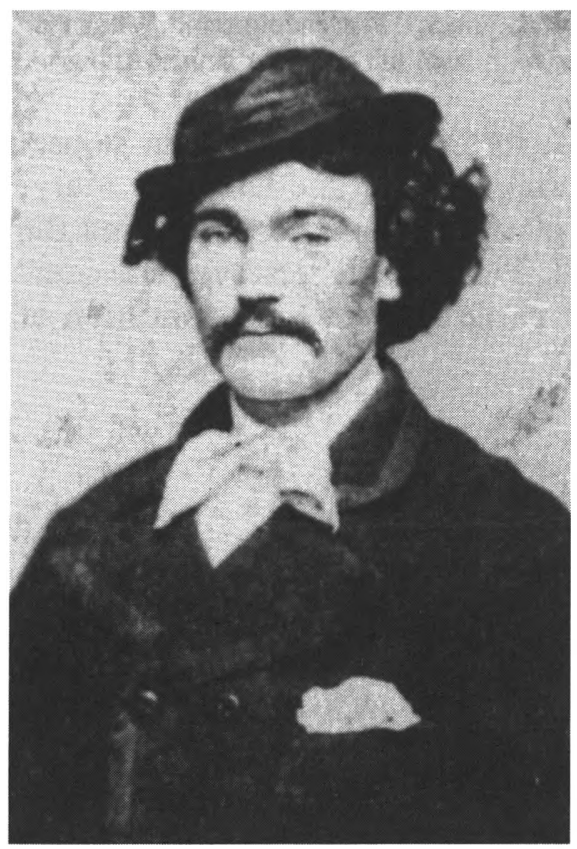

Figure 3. Peter Doyle, 1868. Photograph by $M$. P. Rice, Washington, D.C. Courtesy John Rylands Library, University of Manchester (England), Sixsmith Collection.

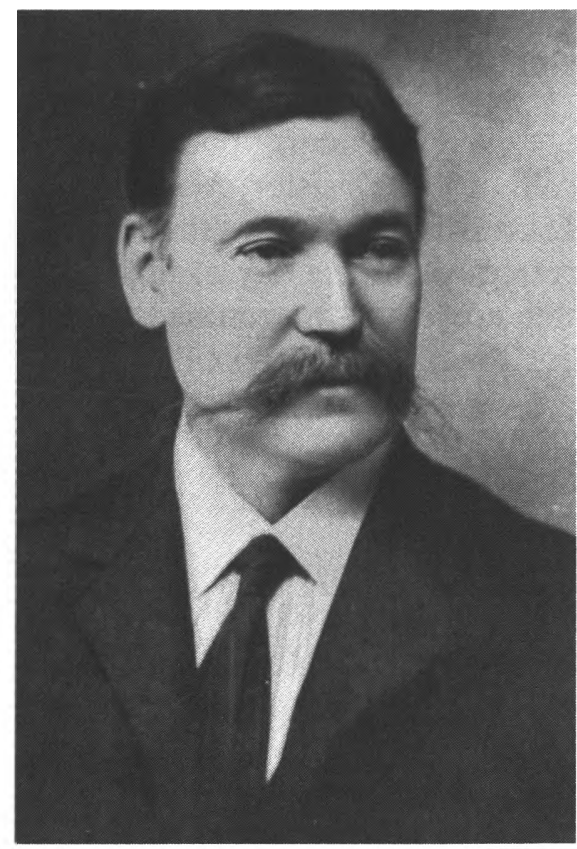

Figure 4. Peter Doyle at age 57. Photograph by Kuebler, Philadelphia.

The finest testament to the friendship between these two "Calamus" lovers was provided by Doyle himself. His poignant remarks about Walt, made years after the older man's death, will ring true in the ears of anyone who has ever been in love:

I have Walt's raglan here [goes to closet-puts it on]. I now and then put it on, lay down, think I am in the old times. Then he is with me again. It's the only thing I kept among many old things. When I get it on and stretch out on the old sofa I am very well contented. It is like Aladdin's lamp. I do not ever for a minute lose the old man. He is always near by. When I am in trouble-in a crisis - I ask myself, "What would Walt have done under these circumstances?" and whatever I decide Walt would have done that I do. (Bucke, 29)

\section{The Washington Friends of Walt Whitman}

\section{NOTES}

1 I dedicate this article to Mary McLaughlin, great-niece of Peter George Doyle, whose desire to learn more about her great-uncle inspired me to write this short biography. I am indebted to Mrs. McLaughlin, and also to John Fragale, Craig Howell, Morgan 
McDonald, Kenneth Plonsky, Peter Scott, Sherwood Smith, and Kurt Vorndran, for reviewing the manuscript and providing me with many helpful suggestions for improvement.

2 Clara Barrus, Whitman and Burroughs: Comrades (Boston: Houghton Mifflin Company, 1931), 82.

3 Walt Whitman, Calamus: A Series of Letters Written During the Years 1868-1880 by Walt Whitman to a Young Friend (Peter Doyle), ed. Richard Maurice Bucke (Boston: Small, Maynard \& Company, 1897), 21.

4 Walt Whitman, Notebooks and Unpublished Prose Manuscripts, ed. Edward F. Grier (New York: New York University Press, 1984), 2:821.

5 Limerick Regional Archives, The Granary, Michael Street, Limerick, Ireland. O'Mahony responded to my request in a May 10, 1993, letter. O'Mahony also researched the information given below on the Doyles' marriage, and the baptismal records for the Doyle children, with the exception of Francis and Margaret, as noted.

6 The Reverend William Flynn, curator of St. John's in Limerick, confirmed the baptismal record for Peter Doyle, Jr., in a July 1, 1993, letter.

7 O'Mahony was unable to find a baptismal record for Francis Michael, a circumstance that O'Mahony says is not unusual. Doyle claimed Francis as his brother. The birth date given for Francis was obtained from his widow's application for a pension. See National Archives, Record Group Number 15, Records of the Veterans Administration, Pension Record for Francis M. Doyle, Private, Captain Clarke's Company, 7th Battalion, D.C. Military Infantry, April 24, 1861 through Fuly 24, 1861.

8 I have approximated the date of Margaret Doyle's birth from the 1860 Richmond Population Census, which gives her age as seven.

9 J. Johnston, M.D., and J.W. Wallace, Visits to Walt Whitman in 1890-1891 by Two Lancashire Friends (New York: Egmont Arens, 1918), 147.

10 National Archives, Record Group Number 36, Records of the United States Customs Service.

11 Mr. Nathan Lipfert, Maine Maritime Museum, 243 Washington Street, Bath, Maine 04530.

12 William Francis Smith and T. Michael Miller, A Seaport Saga: Portrait of Old Alexandria, Virginia (Norfolk/Virginia Beach, VA: The Donning Company, 1989), 73, 77.

13 Ethelyn Cox, Historic Alexandria, Virginia Street by Street: A Survey of Existing Buildings (Alexandria, VA: Historic Alexandria Foundation, 1976), 157.

14 Edward L. Stephens, One Hundred and Fifty Years for Christ, 1795-1945, St. Mary's Church, Alexandria, Virginia, A Brief History of its One Hundred and Fifty Years of Service for Christ (privately published, no date), 18, 19. I reviewed a copy of this book in the Lloyd House Library, Alexandria, Virginia.

15 In 1859, Thatcher Perkins, a former partner in Alexandria's Smith and Perkins Locomotive Works, was engaged as a manager of the machine department for Tredegar Iron Works, in Richmond. See Kathleen Bruce, Virginia Iron Manufacture in the Slave Era (New York: Augustus M. Kelley, 1968), 323n. Perhaps Perkins was instrumental in Doyle's gaining employment at the Richmond foundry. 
16 Charles B. Dew, Ironmaker to the Confederacy, foseph $R$. Anderson and the Tredegar Iron Works (New Haven: Yale University Press, 1966), 18.

17 National Archives, Record Group Number 109, War Department Collection of Confederate Records. Unless otherwise noted, the information on Doyle's service record cited below was obtained from this same source.

18 Robert H. Moore, II, The Richmond Fayette, Hampden, Thomas, and Blount's Lynchburg Artillery (Lynchburg, VA: H.E. Howard, Inc., 1991), 1.

19 Walt Whitman, The Uncollected Poetry and Prose of Walt Whitman, ed. Emory Holloway (New York: Peter Smith, 1932), 2:286.

20 E. H. Chamberlayne, War History and Roll of the Richmond Fayette Artillery, 38th Virginia Battalion Artillery, Confederate States Army, 1861-1865 (Richmond: Everett Waddey, 1883), 4.

21 Fohn Clopton Papers, Special Collections Library, Duke University. I am grateful to Mr. William R. Erwin, Jr., Senior Reference Librarian, for providing me with photocopies of William Clopton's letters.

22 John Michael Priest, Before Antietam: The Battle for South Mountain (Shippensburg, PA: White Mane, 1992), 123.

23 Priest, 197, 215. George W. Whitman, Civil War Letters of George Washington Whitman, ed. Jerome M. Loving (Durham: Duke University Press, 1975), 65, 66.

24 Stephen W. Sears, Landscape Turned Red: The Battle of Antietam (New York: Ticknor \& Fields, 1983), 232-234, 367.

25 September 25, 1862, letter, in the fohn Clopton Papers, Special Collections Library, Duke University.

26 A September 26, 1993, tour of the battle sites of South Mountain and Antietam led by member Craig Howell for The Washington Friends of Walt Whitman, greatly aided my understanding of Doyle's and George Whitman's participation in these battles.

27 National Archives, Record Group 109. See the Compiled Military Service Record of Andrew Baccigalupo, 1st Virginia Artillery, Company I, 1861-1862.

28 Arch Frederic Blakey, General fohn H. Winder, C.S.A. (Gainesville: University of Florida Press, 1990), 147.

29 From September through October 1863, the company muster rolls for the 38th Battalion include the name of George Doyle, with the notation that he is "absent sick since March 18, 1863, Petersburg, Va." The rolls also indicate that Doyle was last paid on November 7, 1862 (the date of his discharge). After October 1863, Doyle is no longer listed on extant company muster rolls. [There are no extant company muster rolls for the periods August 1862 through July 1863, and December 1863 through June 1864 (Moore, 142).]

30 For this quote, I have relied on Horace Traubel's handwritten notes of the Doyle interview in the Feinberg Collection (Container 45), Library of Congress. The published account in Bucke does not mention Doyle's imprisonment. I am grateful to Dr. Alice Birney, curator of the Whitman manuscripts at the Library of Congress, for making me aware of the Traubel manuscript, and alerting me to the fact that the manuscript and the published transcript of the Doyle interview differ in significant respects. 
31 The description of Doyle's confinement is based on my review of records in the "Turner-Baker papers," National Archives, Record Group 94, Records of the Adjutant General's Office. The record does not provide a physical description of Doyle. One possibility is that this is Peter Doyle, Sr. However, there is no indication that the senior Doyle ever came to Washington, D.C. Mary McLaughlin (Peter Doyle's great niece) recalled that her grandmother (Doyle's sister Margaret) told Mary that Margaret lived in Alexandria, Virginia, immediately before moving to Washington, D.C. The first record of Margaret Doyle in Washington is contained in the 1870 Population Census (National Archives, Record Group Number 29), which lists her as living with her widowed mother, Catherine, and her brothers, Peter and Edward.

32 The Old Capitol, situated where the Supreme Court building is today, was so named because it served as the meeting place for Congress for several years, after the British had burned the Capitol building during the War of 1812. Carroll Prison occupied a row of decrepit wooden structures fronting the Capitol between East Capitol and A streets, $\mathrm{SE}$, and received its name from the old Carroll family mansion that had been located nearby. (See Curtis Carroll Davis, "The 'Old Capitol' and Its Keeper, How William P. Wood Ran a Civil War Prison," in J. Kirkpatrick Flack, ed., Records of the Columbia Historical Society of Washington, D.C. (Charlottesville: The University Press of Virginia, 1989), 207.

33 National Archives, Record Group Number 71, Records of the Bureau of Yards and Docks. The payroll record does not provide any identifying information other than name and occupation. The 1864 D.C. directory lists only one Peter Doyle, who is listed as a laborer residing at $62 \mathrm{M}$ Street South, the same address as Francis Doyle and James Doyle.

34 Frank E. Vandiver, Fubal's Raid: General Early's Famous Attack on Washington in 1864 (New York: McGraw-Hill Book Company, Inc., 1960), 144.

35 A physical description of Doyle is found in the Rendezvous Report for the Princeton, March 2, 1865 (National Archives, Record Group Number 24, Records of the Bureau of Ships). Francis Doyle enlisted under his middle name, Michael. Details of Doyle's naval career, given below, were also obtained from this record.

36 National Archives, Record Group Number 15, Records of the Veterans Administration. See Pension Record for Francis M. Doyle, Private, Captain Clarke's Company, 7th Battalion, D.C. Military Infantry, 1861. The birth dates for Doyle's children, given below, were also obtained from this record.

37 The 1860 Population Census for the District of Columbia (National Archives, Record Group 29) lists Francis M. Doyle as a blacksmith at the Navy Yard. I examined the Washington Navy Yard civilian payroll records for the period January 1859 through March 1867 (National Archives, Record Group 71). Francis Doyle is listed as a blacksmith from January 1859 though September 1862. He is not listed thereafter. I am grateful to Ms. Rebecca Livingston of the Archives for her help in obtaining these records.

38 National Archives, Record Group Number 94. See Compiled Military Service Record for Francis M. Doyle, Private, Captain Clarke's Company, 7th Battalion, D.C. Military Infantry, April 24, 1861 through fuly 24, 1861.

39 In some years, Peter George's name is inverted. This also occurred with frequency for Francis Michael. Both Peter and Francis used their middle names as their first names when they enrolled in the military. It is not unusual for a man to use a nickname or a middle name in place of the sissified "Francis." In Peter's case, he may have been called George by the family to distinguish him from his father. 
40 The information on James Doyle's marriage, and the names and ages of his wife and children, were derived from the 1870 Population Census for the District of Columbia (National Archives, Record Group Number 29).

41 A Peter Doyle, age 66, Irish native, died in Manhattan on August 4, 1865, of "Debility." He was buried in Calvary Cemetery. See Vital Records, New York City Department of Records and Information Services, Municipal Archives, New York New York.

42 See the 1870 Population Census for the District of Columbia. Pete's mother was living with Doyle as early as the summer of 1869 , according to a reference made by Whitman in a letter to Pete. See Walt Whitman, The Correspondence, ed. Edwin Haviland Miller (New York: New York University Press) 2:84. The Washington, D.C. directory lists Edward for the first time in 1869.

43 Nash's birth date is inscribed on his gravestone in Congressional Cemetery, Washington, D.C. Nash's obituary in the Washington Evening Star of October 15, 1883, provided a description of his early life in the District.

44 Ann M. Nash's birthdate is inscribed on her gravestone in Congressional Cemetery. Her obituary in Washington, D.C.'s Evening Star on March 27, 1891, states that she was the daughter of Robert and Jane Clarke.

45 See Michael Nash's "Last Will and Testament" filed on October 24, 1883, in the Office of the Register of Deeds for the District of Columbia, D.C. Archives.

46 Sarah Booth Conroy, "Chronicles: Washington's Living Archive," the Washington Post, August 30, 1993.

47 The records of the Association of the Oldest Inhabitants are in the library of The Historical Society of Washington, D.C. (formerly the Columbia Historical Society).

48 Doyle worked a minimum of 21 days per month and a maximum of 25 days per month during the period December 1863 through January 1865. In February 1865, the number of days worked dropped to 19, then in April to 18, and in June to 10 days (March and May 1865 records were not legible). After June 1865, Peter Doyle is no longer listed on the Navy Yard payroll.

49 E.D. Merrill, "Changing Fashions in Transportation," in Records of the Columbia Historical Society (Washington, D.C.: Columbia Historical Society, 1949), vol. 48-49: $161,162$.

50 John W. Boettjer, "Street Railways in the District of Columbia," Master's Thesis, The George Washington University, January 1963.

51 John Burroughs, The Writings of fohn Burroughs (Boston: Houghton Mifflin Company, 1904), 3:220.

52 Joel Sayre, "How I became a true Whitmanite," Book World, December 26, 1971.

53 Mary Catherine was the daughter of Peter Doyle's sister, Margaret. Her daughter, Mary, told me that her mother had made this reference to Uncle Pete when Mary became acquainted with Whitman's work as a student at Barnard College in the 1930s.

54 Charley Shively, Calamus Lovers: Walt Whitman's Working Class Camerados (San Francisco: Gay Sunshine Press, 1987), 38.

55 For a biographical sketch of Vaughan, I have relied on Shively, and on the 1880 Population Census for a Frederick Vaughan of Brooklyn, New York. The Census lists 
Vaughan, 43 years old, an engineer, birthplace Canada, as living at 341 Lexington Avenue with his wife, Frank, 35, a homemaker, and their children Frederick B., 17, an office clerk; Frank C., 15, an office clerk; Harry C., 11, a student; and Mabel L., 1 year old. The name of the oldest boy and the ages of the three boys correspond approximately to the ages given by Vaughan for his children in a November 1874 letter to Whitman (Shively, 50). In that letter, Vaughan also mentioned a fourth son. This boy probably died in his youth; he is not listed in the 1880 Census. The 1900 Census for Schenectady, New York, lists what I assume to be the family of Fred's son, Frederick. He lived with his wife, Mary, and daughter, Maybelle, and his widowed mother, Frances. The 1900 Census also reported that Fred, Jr., was born in January 1863 and that his mother was born in January 1846. The 1900 Census further noted that Frances had given birth to five children, of whom only three were still living at the time of the Census.

56 Edward "Ned" Stewart testified to Doyle's fondness for limericks in a February 25, 1870 , letter to Whitman (Shively, 111).

57 See Whitman's manuscript of this poem in the Feinberg Collection (Container 27), Library of Congress.

58 Walt Whitman, Leaves of Grass: A Textual Variorum of the Printed Poems, ed. Sculley Bradley, Harold W. Blodgett, Arthur Golden, and William White (New York: New York University Press, 1980), 2:488.

59 Whitman used the personal name "Jonathan" in A Boston Ballad, first published in the 1855 edition. The name was not meant to represent a fictional hero as in Come Up From the Fields Father. Rather, as Jerome Loving has noted, Jonathan was a "term used to denote the average American in the nineteenth century" (see Walt Whitman, Leaves of Grass, ed. Jerome Loving [New York: Oxford University Press, 1991], 469).

60 Florence Bernstein Freedman, William Douglas O’Connor, Walt Whitman's Chosen Knight (Athens, Ohio: Ohio University Press, 1985), 198-199.

61 Dr. William Tindall, "Beginnings of Street Railways," Records of the Columbia Historical Society (Washington, D.C.: 1918), 21:49-50.

62 I have relied on Traubel's original interview notes in the Feinberg Collection which describe these incidents in greater detail than the published account in Bucke.

63 See the 1870 Georgetown and Washington, D.C. Directory.

64 James M. Goode, Capital Losses: A Cultural History of Washington's Destroyed Buildings (Washington, D.C.: Smithsonian Institution Press, 1979), 167-168.

65 Horace Traubel, With Walt Whitman in Camden (New York: D. Appleton \& Co., 1908), 2:511-512.

66 This is taken from Traubel's notes (Feinberg Collection). Bucke does not identify the newspaperman.

67 Ed Folsom, "1868 Photograph of Peter Doyle," Walt Whitman Quarterly Review 4 (Spring 1987), 38 and back cover.

68 Whitman and Doyle corresponded with each other over a twenty-year period. Although many of Whitman's letters have survived, only nine of Doyle's letters are extant. Charley Shively has reproduced all of the surviving Doyle letters to Whitman (Shively, 104-114). Of the nine surviving letters, seven were written in the Summer/Fall of 1868 , one was written in November 1875, and one in January 1878. 
69 Daily Morning Chronicle, September 10, 1869, Washington, D.C. Like Burroughs in his tribute to Doyle as a "mute, inglorious Whitman," the copy writer of this advertisement also borrowed heavily from Thomas Gray's Elegy Written in a Country Churchyard.

70 See the September 28, 1904, letter from Henry Bryan Binns to Edward Carpenter in the Feinberg Collection, Library of Congress.

71 I have dated this outing by cross-referencing Whitman's known visits to his mother in her Portland Avenue home (from the Correspondence), with New York performances of the opera (Poliuto, as reported in George Odell, Annals of the New York Stage [New York: AMS Press, 1970]).

72 Traubel's manuscript of this interview quotes Doyle as saying, "I stayed in Jersey City."

73 Robert D. Faner, Walt Whitman E Opera (Carbondale: Southern Illinois University Press, 1951), 10, 13, 108.

74 NUPM, 887. Interestingly, an 1850s photograph (in the collection of The Historical Society of Washington, D.C.) of a Washington horsecar along Doyle's route from the War \& Navy Departments to the Capitol has the number " 16 " emblazoned upon it. In his letters to Doyle, Whitman sometimes referred to transportation men by their car numbers.

75 See Alan Helms, "Whitman's 'Live Oak with Moss' " in Robert K. Martin, ed., The Continuing Presence of Walt Whitman (Iowa City: University of Iowa Press, 1992), 185-205.

76 I discuss this episode in detail in an upcoming article for The Yale University Library Gazette.

77 George H. Burgess and Miles C. Kennedy, Centennial History of The Pennsylvania Railroad Company (Philadelphia: The Pennsylvania Railroad Company, 1949), 276.

78 The description of a brakeman's duties was obtained from this source: B.B. Adams, Jr., "The Every-Day Life of Railroad Men" in The American Railway (New York: Charles Scribner's Sons, 1889), 383-398. I am grateful to Robert L. Emerson of the Railroad Museum of Pennsylvania for providing me with this resource.

79 The Nash home, in which Whitman slept, is still standing.

80 Corr., 2:342n. See also Record Group 56, National Archives, Washington, D.C.

81 Walt Whitman, Daybooks and Notebooks, ed. William White (New York: New York University Press, 1978), 1:79.

82 Richard Maurice Bucke, Richard Maurice Bucke, medical mystic: Letters of Dr. Bucke to Walt Whitman and His Friends, ed. Artem Lozynsky (Detroit: Wayne State University Press, 1977), 70-71, 72n.

83 The manuscript of Bucke's draft of the biography with Whitman's markings is in the collection of the Duke University Library. Apparently, Bucke planned to mention Whitman's friendship with Doyle by excerpting John Burroughs' description of the two on the Washington streetcars that I cited above. This section, however, is marked through for deletion (presumably by Whitman) in draft page 60, and was not printed.

84 The information on Mrs. Doyle's interment was provided to me by John Hanley of The Association for the Preservation of Historic Congressional Cemetery. 
85 The information on the Elks was provided to me by Mike Kelly of the Elks's National Headquarters.

86 Although the lodge itself closed in 1972, the building housing Doyle's Elks still stands.

87 Robert E. Lee Camp No. 1 Roster, 18 April 1883 - 8 March 1918. The roster is in the manuscript collection of the Virginia State Library and Archives, Archives and Records Division, in Richmond, Virginia. See also Roster of Officers $\mathcal{E}$ Members of R.E. Lee Camp, No. 1, Confederate Veterans, dated August 1890, January 1900, and January 1, 1913, in the manuscript collection of the Virginia Historical Society (Richmond).

88 The roster lists him as "P.G. Doyle," shows his address as Philadelphia, Pennsylvania, his age at joining as 44 years, his birthplace as Alexandria, Virginia, his date of death as May 24, 1907, and under "remarks" that he "served until the end of the War."

89 See Confederate Veteran 3 (October 1895), 312-313, and 6 (April 1898), 160.

90 Ed Folsom was good enough to provide me with a transcript of the unpublished portions of Traubel's With Walt Whitman in Camden manuscript that pertain to Doyle. The above-cited conversation took place on Monday, July 20, 1891.

91 Walt Whitman, Prose Works 1892, ed. Floyd Stovall (New York: New York University Press, 1963), 1:111.

92 Traubel's published account of Whitman's last years now extends through February 10, 1891 (Horace Traubel, With Walt Whitman in Camden, Vol. 7 (Carbondale: Southern Illinois University Press, 1992).

93 I found this letter, dated "November 1944," tucked inside an autographed copy of Bucke's Calamus that is part of the Oscar Lion Collection in the New York City Public Library.

94 Henry Bryan Binns, A Life of Walt Whitman (London: Methuen \& Co., 1905), 344.

95 Jerome Loving, "Emory Holloway and the Quest for Whitman's 'Manhood,' "Walt Whitman Quarterly Review 11 (Summer 1993), 7, 16.

96 Conservator, September, 1907.

97 John Addington Symonds, Walt Whitman, A Study (London: John C. Nimmo, 1893), 78-79.

98 Clara Barrus, The Life and Letters of Fohn Burroughs (Boston: Houghton Mifflin Company, 1925), 1:340.

99 See the November 1944 letter from Anne Montgomerie Traubel to Oscar Lion cited above.

100 Feinberg Collection (Container 53), Library of Congress.

101 July 18,1897, letter from Ellen M. Calder to Richard Bucke, Feinberg Collection (Container 53), Library of Congress.

102 Feinberg Collection (Container 52), Library of Congress.

103 The death dates for Ann Nash and Edward Doyle were obtained from their respective gravestones.

104 City of Philadelphia, Register of Wills, Index \# A 965, Year 1907. 